\title{
Taxonomic revision of the genus Wurdastom (Melastomataceae: Cyphostyleae)
}

\section{Revisión taxonómica del género Wurdastom (Melastomataceae: Cyphostyleae)}

\section{Acta Botanica Mexicana}

\author{
Humberto Mendoza-Cifuentes ${ }^{1,2}$ (iD)
}

\begin{abstract}
:
Background and Aims: Wurdastom is a little-known neotropical genus, which is poorly represented in herbarium collections. A historical summary, discussion about the tribal position, taxonomic review, and a conservation assessment of each species of the genus was carried out.

Methods: Wurdastom specimens of 17 herbarium collections from Colombia (CAUP, COAH, COL, CUVC, FMB, HUQ, PSO, UDBC, UPTC, VALLE), ECuador (QCA, QCNE), and the United States of America (CAS, F, MO, NY, US) were reviewed, and relevant type collections available at JSTOR Global Plants were consulted. An identification key, descriptions, illustrations and distribution maps for each species were developed. IUCN guidelines and criteria were used for conservation assessments of each species.

Key results: In total, 52 Wurdastom collections were found in the revised herbaria. A new species from Colombia is described and new isotypes from the VALLE Herbarium are reported here for the first time. Wurdastom is a small genus of trees and shrubs from central-west Colombia to northern Peru where it grows in Andean and humid lowland tropical forests. The genus, which is assigned to the tribe Cyphostyleae, is characterized by the acrodromous venation, barbellate trichomes on vegetative parts and inflorescences, multiflorous thyrsoid or pleiothyrsoid inflorescence, haplostemonous flowers, petals $\leq 1 \mathrm{~cm}$ long, inferior ovaries, and capsular fruits.

Conclusions: Wurdastom includes eight neotropical species, most of them with restricted distributions. One species is assessed here as Threatened (W. sneidernii), two as Vulnerable (W. cuatrecasasii, W. dudleyi), and the rest are treated as Data Deficient.

Key words: Allomaieta, Alloneuron, Cyphostyleae, Neotropics, Taxonomy.

\section{Resumen:}

Antecedentes y Objetivos: Wurdastom es un género neotropical poco conocido y pobremente representado en colecciones de herbario. Se realizó una síntesis histórica, discusión de su posición tribal, revisión taxonómica y un análisis del estado de conservación de las especies del género.

Métodos: Se revisaron ejemplares de Wurdastom de 17 herbarios en Colombia (CAUP, COAH, COL, CUVC, FMB, HUQ, PSO, UDBC, UPTC, VALLE), ECuador (QCA, QCNE) y Estados Unidos de América (CAS, F, MO, NY, US) y se consultaron los ejemplares tipo disponibles en JSTOR Global Plants. Se elaboró una clave de identificación, así como descripciones, ilustraciones y mapas de distribución de cada una de las especies. Se emplearon las pautas y los criterios de la UICN para las evaluaciones de conservación de todas las especies del género.

Resultados clave: En total, se encontraron 52 colecciones de Wurdastom en los herbarios revisados. Se describe una especie nueva de Colombia y se documentan isotipos no conocidos con anterioridad procedentes del herbario VALLE. Wurdastom es un género pequeño de árboles y arbustos distribuidos desde el centro-occidente de Colombia hasta el norte de Perú, en bosques andinos y húmedos de zonas bajas. El género forma parte de la tribu Cyphostyleae y se caracteriza por la venación acródroma de las hojas, presencia de tricomas barbelados en las estructuras vegetativas e inflorescencia, inflorescencias multifloras tirsoides o pleiotirsoides, flores haplostemonas, pétalos $\leq 1 \mathrm{~cm}$ de largo, ovario ínfero y frutos capsulares. Conclusiones: Wurdastom comprende ocho especies neotropicales, la mayoría de distribución restringida. Se evalúa una especie como Amenazada (W. sneidernii), dos como Vulnerable (W. cuatrecasasii, W. dudleyi) y el resto puede ubicarse en la categoría de Datos Insuficientes.
\end{abstract}

Palabras clave: Allomaieta, Alloneuron, Cyphostyleae, Neotrópico, taxonomía.

${ }^{1}$ Instituto Alexander von Humboldt, Herbario FMB, Carrera 8 \#15-08, Claustro de San Agustín, Villa de Leyva, Boyacá, Colombia.

${ }^{2}$ Author for correspondence: hmendoza@humboldt. org.co
Received: November 26, 2019.

Reviewed: January 24, 2020.

Accepted by Gilberto Ocampo: March 3, 2020.

Published Online first: March 31, 2020.

Published: Acta Botanica Mexicana 127 (2020).
To cite as: Mendoza-Cifuentes, H. 2020. A taxonomic revision of the genus Wurdastom (Melastomataceae: Cyphostyleae). Acta Botanica Mexicana 127: e1642. DOI: 10.21829/abm127.2020.1642 


\section{Introduction}

Wurdastom B. Walln. is a small genus of trees and shrubs restricted to the neotropical region from central-west Colombia to northern Peru, where it grows in Andean to humid tropical forests (Wallnöfer, 1996). This genus belongs to the tribe Cyphostyleae and currently consists of eight species (Michelangeli et al., 2011). The genus is unique among the Neotropical Melastomataceae in having thyrsoid multiflorous inflorescences, haplostemonous flowers, an inferior ovary, and capsular fruits.

Wurdastom has never been the subject of a comprehensive study. What has been known about the genus consists mostly of original descriptions of the species, and only two published studies focus on this genus. Mendoza-Cifuentes and Fernández-Alonso (2010) discuss homologies of calyx and stamen characters for the tribe Merianieae and included the current Wurdastom species. Michelangeli et al. (2011) performed a phylogenetic analysis of the tribe Cyphostyleae that included a species of Wurdastom.

There are few collections of the species of the genus in neotropical herbaria and some species are only known from the type collections. Often in herbaria, they are confused with other genera that have terminal inflorescences of small flowers. The purpose of this study is to clarify the circumscription of Wurdastom, as well as to document its taxonomic history, tribal position, affinities with other genera, and provide a comprehensive treatment of each species.

\section{Materials and Methods}

This review is based on the examination of herbarium specimens and complemented with protologues and type images of every species of Wurdastom. In total, 52 collections were examined from the following herbaria: Colombia, CAUP (Universidad del Cauca), COAH (Instituto SINCHI), CUVC (Universidad del Valle), COL (Universidad Nacional de Colombia sede Bogotá), FMB (Instituto Alexander von Humboldt), HUQ (Universidad del Quindío), PSO (Universidad de Nariño), UDBC (Universidad Distrital de Bogotá), UPTC (Universidad Pedagógica y Tecnológica de Colombia), VALLE (Universidad Nacional de Colombia sede Palmira); United States of America, CAS (California Academy of Sciences), $\mathrm{F}$ (The Field Museum of Chicago), MO (Missouri
Botanical Garden), NY (New York Botanical Garden), US (Smithsonian Natural Museum of Natural History); Ecuador, QCA (Pontificia Universidad Católica del Ecuador), QCNE (Museo Ecuatoriano de Ciencias Naturales). Measurements were based on dry and rehydrated material when possible, but in some species only protologue information was available. Microphotography of trichomes, seeds, and pollen was taken with a scanning electron microscope (SEM) (Hitachi S-50, Schaumburg, IL, USA) at the Botany Department of the California Academy of Sciences, in which specimen stubs were affixed to rectangular segments of double-stick tape on aluminum and sputter-coated with gold palladium. A key, descriptions, diagnostic illustrations, and distribution maps of all species of the genus are presented. Preliminary conservation assessments are included using the Area of Occupancy with GeoCat (Bachman and Moat, 2012) and applying the International Union for Conservation of the Nature Red List guidelines and criteria (IUCN, 2017).

\section{Results}

\section{Taxonomic history}

Wurdastom species were described under Alloneuron Pilg. in a series of articles published by Wurdack (1971; 1974; 1981; 1990). Wurdack (1971) described four species as Alloneuron that are now placed in Wurdastom: A. cuatrecasasii Wurdack, A. bullatum Wurdack, $A$. subglabrum Wurdack from El Valle in the Colombian Cordillera Occidental, and A. dudleyi Wurdack from the Cordillera del Condor in Peru. In this latter article, Wurdack also provided a key in which current species of Wurdastom were differentiated from Alloneuron by the pinnate venation (vs. brochidodromous venation in Wurdastom) and presence of stellate trichomes (vs. barbellate trichomes).

Later, Wurdack described A. hexamerum Wurdack and $A$. sneidernii Wurdack from collections by Kjell von Sneidern from the Pacific foothills of the Cordillera Occidental of Colombia (Cauca department). Finally, Wurdack (1981, 1990) described A. ecuadorense Wurdack and A. dorrii Wurdack from the Carchi and Zamora-Chinchipe provinces of Ecuador.

Wurdack recognized the uniqueness of the character combination of haplostemonous flowers, inferior ovaries, and capsular fruits present in all these species, which in 
his view limited the generic placement to only Alloneuron, Cyphostyla Gleason (=Allomaieta Gleason) and Allomaieta. This character combination is uncommon in Melastomataceae, and only constantly present in the genera of the tribe Cyphostyleae (Wurdack, 1971; Wallnöfer, 1996; Lozano and Becerra, 1999; Michelangeli et al., 2011, 2014).

Wurdack's decision to describe the new species in the genus Alloneuron is unclear. Given the uncertainty and scarce knowledge of the tribe Cyphostyleae at that time, Wurdack had doubts about which genus the new species from Colombia and Peru should be assigned to. He literally wrote: "the present collections of the Cyphostyleae are quite inadequate for further generic elucidation... the three El Valle (Colombia) collections of Alloneuron (the new species) have been generic irritations for me during the last 15 years" (Wurdack, 1971).

In his article of 1971, Wurdack does not mention anything about the main characters of Cyphostyleae, which is the style with the curved apex, but it is possible that the absence of this character in the new species, together with the type of inflorescence, size of the flowers, and the number of locules, led him to associate these with Alloneuron. The new species shared with Alloneuron the helicoid branchlets of the inflorescence, the small flowers, stamen connective with a basal appendage, straight style, and the trilocular ovary. He emphasized that the genera Cyphostyla and Allomaieta have large flowers, inappendiculate anthers, and 5-locular ovaries.

Wallnöfer (1996) segregated the species described in Alloneuron by Wurdack into the new genus Wurdastom based on differences between the two genera according to the following characteristics: Alloneuron are nonwoody herbs with pinnate venation, stellate trichomes, and 4-5-merous flowers; Wurdastom are woody bushes or trees with no stellate trichomes, acrodromous venation, and 4-9-merous flowers. Other differences found during this study not documented before by Wallnöfer (1996) include the shape of the seeds and type of inflorescence: Alloneuron has ovate seeds with a tuberculate testa and helicoid inflorescences, whereas in Wurdastom the seeds are cuneiform or L-shaped with a smooth testa and thyrsoid multiflorous inflorescences.

\section{Tribal and generic affinities}

Wurdack (1981) considered that Alloneuron (pro parte $=$ Wurdastom) belonged to the tribe Cyphostyleae. Cyphostyleae was proposed by Gleason (1929) for those taxa with calyptriform deciduous calyces, haplostemonous flowers, S-shaped filaments, style with the apex sharply curved or recurved, inferior ovary, capsular fruit and straight seeds. The tribe initially consisted of the genera Cyphostyla and Allomaieta. However, the tribe was assigned to Miconieae by Renner (1993), which she justified on the basis of its inferior ovary and lack of staminal pedoconnectives.

Lozano and Becerra (1999) argued for the necessity of restoring the tribe Cyphostyleae and documented a general combination of characters that support this clade, including plinervate acrododromous venation, calyptrate calyx, inferior ovary, axillary placentation, uncinate and apically enlarged style, dry capsular fruits, and pyramidal seeds.

Michelangeli et al. (2011), in their phylogeny based on molecular and morphological characters, concluded that the tribe Cyphostyleae is a monophyletic group composed of the genera Alloneuron, Allomaieta, and Wurdastom, and can be diagnosed by the combination of haplostemonous flowers, partially or completely inferior ovaries, and capsular fruits. In their phylogeny, Wurdastom is represented by a single species (W. cuatrecasasii (Wurdack) B. Walln.); however, many of the characters of this species are shared with the type species of the genus (W. dudleyi (Wurdack) B. Walln.). The only synapomorphy cited for Wurdastom in this work is the regular hypanthial dehiscence following ovary locules.

Currently, Cyphostyleae comprises four genera, including Quipuanthus Michelang. \& C. Ulloa (Michelangeli et al., 2014). The differences among Wurdastom and the other genera of the tribe are mainly based on the type of habit, trichomes, and inflorescence (Table 1). Wurdastom differs from Alloneuron mainly in the habit, venation, type of trichomes, and inflorescence. The ornamentation of the seeds in Wurdastom is smooth, while in Alloneuron it is tuberculate. From Allomaieta, Wurdastom differs in flower size, type of inflorescence, and filament and style shape. Quipuanthus differs widely in growth habit, type of inflorescence, and shape of the style. 
Table 1: Distinguishing characteristics of the genera of Cyphostyleae. Based on Gleason (1929, 1933), Wallnöfer (1996, 1999), Lozano-C. and Lozano Becerra (1999), Mendoza and Ramírez (2006), and Michelangeli et al. (2011).

\begin{tabular}{|c|c|c|c|c|}
\hline \multirow[b]{2}{*}{ Character } & \multicolumn{4}{|c|}{ Genera } \\
\hline & Allomaieta Gleason & Alloneuron Pilg. & Wurdastom B. Walln. & $\begin{array}{l}\text { Quipuanthus Michelang. } \\
\text { \& C. Ulloa }\end{array}$ \\
\hline Habit & Shrubs & Herbs, shrubs & Shrubs, trees & Herbs, rosette-like \\
\hline Predominant trichomes & Elongated smooth & Stellate, glandular & $\begin{array}{l}\text { Elongated slightly } \\
\text { roughened or barbellate }\end{array}$ & $\begin{array}{l}\text { Elongated smooth, } \\
\text { glandular }\end{array}$ \\
\hline Leaf symmetry & $\begin{array}{l}\text { Isophyllous and } \\
\text { anisophyllous }\end{array}$ & $\begin{array}{l}\text { Isophyllous and } \\
\text { anisophyllous }\end{array}$ & Isophyllous & Unknown \\
\hline Leaf venation & Acrodromous & Pinnate and acrodromous & Acrodromous & Acrodromous \\
\hline Inflorescence & $\begin{array}{l}\text { Simple dichasium, } \\
\text { terminal }\end{array}$ & $\begin{array}{l}\text { Helicoid cyme, terminal or } \\
\text { lateral }\end{array}$ & $\begin{array}{l}\text { Thyrsoid or pleiothyrsoid, } \\
\text { terminal or lateral }\end{array}$ & Helicoid cyme, lateral \\
\hline Flower merosity & $5-6$ & $4-5$ & $4-10$ & 5 \\
\hline Petal length & $8-36 \mathrm{~mm}$ & $1.3-4.5 \mathrm{~mm}$ & $1-10 \mathrm{~mm}$ & $14-17 \mathrm{~mm}$ \\
\hline Calyx type & Calyptrate & $\begin{array}{l}\text { Subcalyptrate or } \\
\text { calyptrate }\end{array}$ & $\begin{array}{l}\text { Lobulate, subcalyptrate or } \\
\text { calyptrate }\end{array}$ & Lobulate \\
\hline Filament shape & S-shaped & Straight, with apical elbow & Straight, with apical elbow & Straight, with apical elbow \\
\hline Style shape & Apically curved & Straight & Straight & Apically curved \\
\hline Number of locules & $2-5$ & $2-5$ & $2-5$ & 3 \\
\hline Capsule shape and dehiscence & $\begin{array}{l}\text { Campanulate, opening by } \\
\text { lateral slits }\end{array}$ & $\begin{array}{l}\text { Subspheric, opening by } \\
\text { irregular slits }\end{array}$ & $\begin{array}{l}\text { Campanulate, opening by } \\
\text { lateral slits }\end{array}$ & $\begin{array}{l}\text { Turbinate, apically } \\
\text { dehiscent by bivalved } \\
\text { openings }\end{array}$ \\
\hline Seed shape & Pyramidal & Ovoid & Pyramidal and L-shaped & Ovoid \\
\hline
\end{tabular}

Based on this, Wurdastom can be separated from the other genera of Cyphostyleae by the following unique character combination: shrub or tree, acrodromous venation, barbellate trichomes on vegetative parts and inflorescences, multiflorous thyrsoid or pleiothyrsoid inflorescence, and petals $\leq 1 \mathrm{~cm}$ long.

Almeda et al. (2016) included the illegitimate name Wurdastom trimera Almeda et al. in the Catalogue of Plants and Lichens of Colombia based on collections from the department of Valle del Cauca. This taxon corresponds to a new species, but there is no certainty that it corresponds to the genus Wurdastom considering the previous set of char- acters, and because it has glandular and non-barbellate trichomes. Therefore, $W$. trimera is not considered further in this treatment.

The following key separates the current genera of Cyphostyleae:

1a. Leaf venation pinnate Alloneuron Pilg.

1b. Leaf venation acrodromous ......................................... 2

2a. Style straight …....................................................... 4

2b. Style with the apex sharply curved or recurved .......... 3

3a. Shrubs, inflorescence a simple cyme, calyx calyptrate Allomaieta Gleason 
3b. Herbs, inflorescence a helicoid cyme, calyx lobulate Quipuanthus Michelang. \& C. Ulloa

4a. Indument of barbellate or roughened trichomes Wurdastom B. Walln.

4b. Indument of glandular or stipitate-stellate trichomes Alloneuron Pilg.

\section{Wurdastom morphology}

Habit: erect shrubs or trees of 0.5-10 m height.

Indumentum: plants with different types of indumentum and trichomes, rarely glabrous. The types of trichomes range from simple and smooth or conic with greatly roughened to dendritic hairs with a short axis and few terete arms. The types of trichomes found in the genus following the descriptive terminology and classification proposed by Wurdack (1986; Fig. 1) are:

Type 11 - Elongated smooth or fluted hairs (Fig. 1F).

Type 12 - Elongated alveolate eglandular hairs (Fig. 1E).

Type 15 - Bulla-based hairs without enations. Only present on the abaxial surface of the leaf blades.

Type 16 - Elongated slightly roughened hairs. These may be roughened only at the base or over entire body (Fig. 1C).

Type 19 - Conic densely roughened hairs. These are described as barbellate trichomes, which are prevalent in most species (Figs. 1A, B).

Type 25 - Dendritic hairs with a short axis and few terete arms. They are regularly minute-short and with ramifications at the base or throughout the trichome length (Figs. $1 D, G)$.

Other types of hairs not documented by Wurdack are roughened amorphous trichomes, erect or appressed.

Leaves and venation: phyllotaxy in Wurdastom is opposite and decussate. Opposing leaves at a node are equal in size (isophyllous) or nearly so, and petiolate. Leaf blades are thin and coriaceous, margins entire to dentate. Venation acrodromous; in most species it is plinerved, but in $W$. subglabra (Wurdack) B. Walln. the veins may be basal.

Inflorescences: all species have terminal inflorescences with the exception of $W$. lateriflora Humberto Mend. The inflorescences are thyrsoid or pleiothyrsoid, multiflorous, without bracts and bracteoles or early bracteoles caducous. The apex of the inflorescence branchlets are helicoid, but this is difficult to observe due to the congested flowers.
Flowers: the flowers are 4-10-merous and haplostemonous. They are is $0.3-1.5 \mathrm{~cm}$ long including the pedicel; regularly sessile or short pedicellate.

Hypanthia: fused to the ovary, cupuliform or obconical; apical thalamus free (from the ovary) with internal partition walls.

Calyx: with lobes, subcalyptrate or calyptrate and opening by irregular lobes.

Petals: obovate to oblong-lanceolate; apex acute, rounded or truncate; white, cream or pink; glabrous or puberulous.

Stamens: equal in number to the petals, the antepetalous whorl is missing. Mendoza-Cifuentes and Fernández-Alonso (2010) documented non-geniculate stamens for all species of Wurdastom and the presence of a triangular structure at the apex of the filament that is denominated "elbow". The non-geniculate stamen character is defined as the absence of a curved portion or joint in the filament during the bud phase which during the anthesis decongests (Mendoza-Cifuentes and Fernández-Alonso, 2010). The absence of a curved part of the filament causes the anther to be arranged at a right or acute angle with respect to the filament once the flowers open, and this condition is a product of the fusion of tissues at the apex of the filament and the base of the connective (Mendoza-Cifuentes and Fernández-Alonso, 2010).

The non-geniculate stamen is a character associated with the main genera of the tribe Merianieae, such as Adelobotrys DC., Axinaea Ruiz \& Pav., Graffenrieda DC., and Meriania Sw. In Cyphostyleae this characteristic is also present in Alloneuron, and in Quipuanthus where there is a very similar condition, although the elbow is not triangular.

The anthers in Wurdastom are oblong to obovate, with a dorsally-oriented tiny pore. The connective is does not have appendages or is slightly expanded laterally (Fig. 2).

Ovary: inferior, 2-5-locular; apically truncate or with appendages that form a continuum with the internal partition walls of the hypanthium. Placenta with seminal rudiments on all surfaces. Style columnar or slightly columnar, straight or slightly curved toward apices; stigma slightly widened.

Fruit: loculicidal capsule, less than $0.5 \mathrm{~cm}$ in diameter and opening by lateral slits, with abundant seeds. In $W$. 

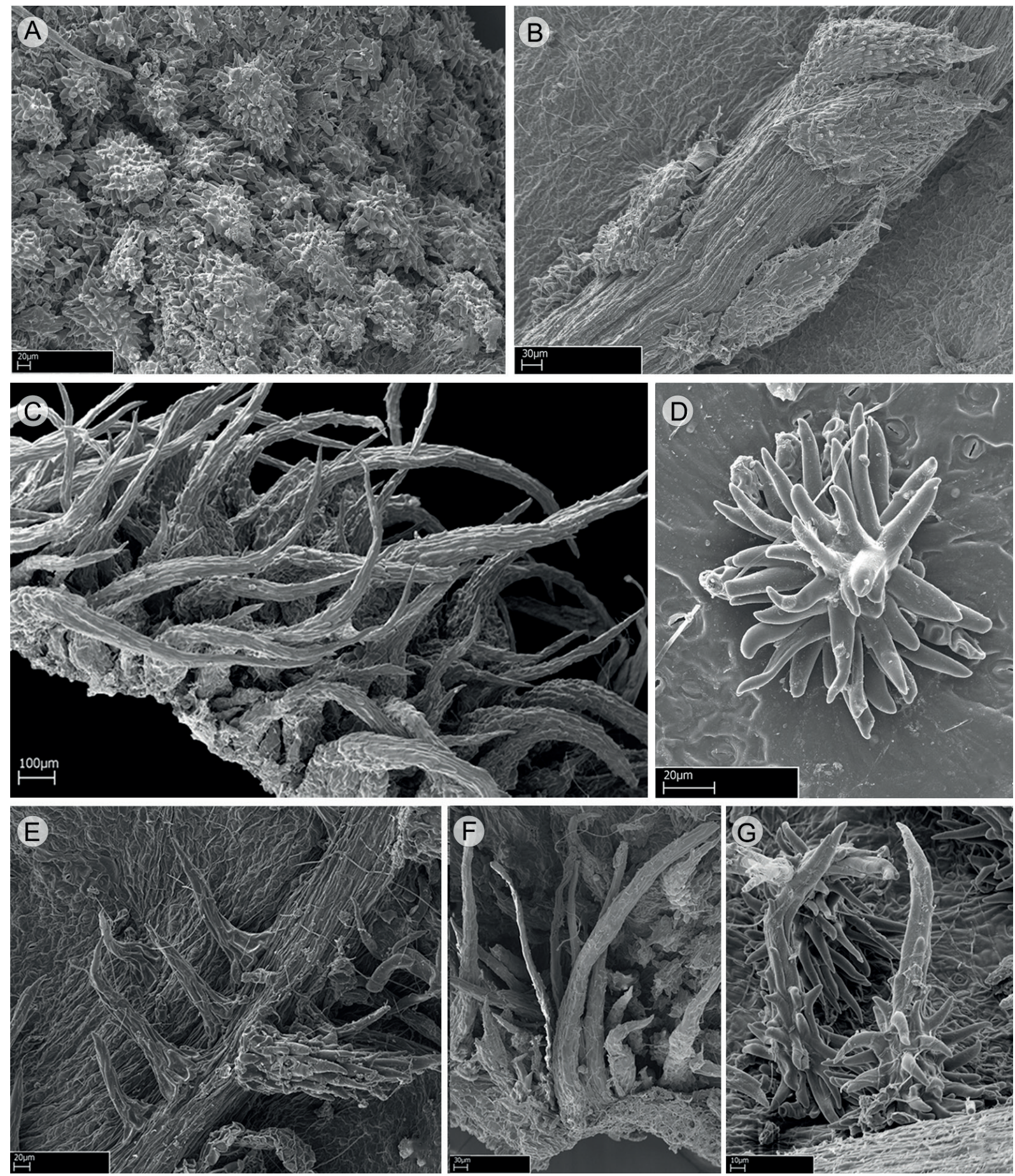

Figure 1: SEM photomicrograph of trichomes of Wurdastom B. Walln. Wurdastom cuatrecasasii (Wurdack) B. Walln.: A. hypanthial trichome; B, D. trichome from abaxial leaf surface. W. hexamera (Wurdack) B. Walln.: C. hypanthial trichome. W. sneidernii (Wurdack) B. Walln.: E. trichome on abaxial leaf surface. W. bullata (Wurdack) B. Walln.: F. petiolar trichome; G. trichome from abaxial leaf surface. A, D from Cuatrecasas 15565 (VALLE); B from García 06 (FMB); C from Almeda 10279 (CAS); E from Díaz 8 (FMB); F, G from Cuatrecasas 22475 (VALLE).

hexamera (Wurdack) B. Walln. and W. sneidernii (Wurdack) B. Walln. the infructescence wilts and sheds as a unit.

Seeds: two types of seeds are present in Wurdastom: the first type of seeds have a pyramidal shape and no apical appendices in the chalazal zone (W. bullata (Wurdack) B. Walln., W. cuatrecasasii, W. dorri (Wurdack) B. Walln., W. dudleyi, W. lateriflora and W. subglabra), while the second type of seeds are L-shaped with a cordiform appendage in 


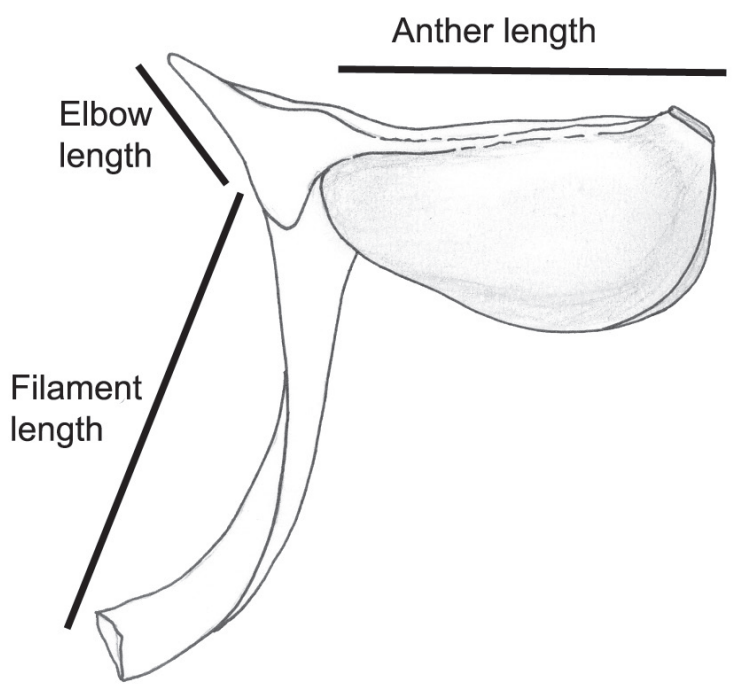

Figure 2: Representative stamen of Wurdastom B. Walln.

the chalazal zone 2-3 time longer than the embryo portion ( $W$. hexamera and $W$. sneidernii). The seed size is variable and ranges between 0.6-1.5 $\mathrm{mm}$ long. The testa is smooth (Fig. 3).

Pollen: as in other genera of Neotropical Melastomataceae, the pollen of Wurdastom is radiosymmetric, isopolar, globose, and 6-colpate but with only three of these having a single pore (tricolporate-tricolpate). The exine sculpture is striate-rugulate. The size ranges between 9-11 mm (Fig. 4).

\section{Distribution and habitat}

Like the other nearly 60 genera of Melastomataceae, Wurdastom is restricted to tropical zones of the Americas (Almeda and Robinson, 2011). Its distribution ranges from the western and central Andes of Colombia to northern Peru in the Andean and tropical humid forest, and from sea level to $2300 \mathrm{~m}$ elevation. Five species are restricted to the Andean region and the Chocó biogeographic province of Colombia, two species occur in southern Ecuador and the Cordillera de Vilcabamba in Peru, and one species is shared between Colombia and Ecuador (W. sneidernii). A majority of the species are known only from a few records and indicate high incidence of local endemism based on current sampling.

Following the Van der Hammen and Rangel-Ch. (1997) classification of vegetation types for Colombia, the habitats in which Wurdastom grows are subandean and Andean forests and tropical humid forests. Direct observations in the field indicate that the species grow only in pristine undisturbed forest in shaded conditions.

\section{Taxonomic treatment}

Wurdastom B. Walln.

TYPE: Wurdastom dudleyi (Wurdack) B. Walln., Ann. Naturhist. Mus. Wien, Ser. B, Bot. Zool. 98B(Suppl.): 461. 1996.

Erect shrubs or trees, glabrous or with indumentum of barbellate, dendritic or amorphous trichomes; leaves opposite, isophyllous and petiolate; venation acrodromous and regulary plinerved; inflorescences terminal or rarely axillary, thyrsoid, with helicoid branches, multiflorous; bracts and bracteoles early caducous or absent; flowers haplostemonous, 4-10-merous, sessile or short pedicellate; hypanthia with apical thalamus and internally with partition walls; calyx lobulate to calyptrate and rupturing into irregular deciduous lobes; petals obovate, 1-10 mm long, color white, cream or pink; stamens antesepalous, the antepetalous ones missing, not geniculate, filament apices with a triangular and laterally expanded elbow, anther thecae oblong to oblong-obovate, with a dorsally oriented pore, connective not prolonged and without appendages; style cylindrical, straight or slightly curved at the apices in anthesis, stigma slightly expanded; ovary inferior, 2-5-locular, placenta with seminal rudiments on all surfaces; capsule loculicidal, opening by lateral slits; seeds with a straight embryo, cuneiform or L-shaped (by the presence on the chalazal zone of a cordiform appendage larger than body embryo), testa smooth.

The genus consists of eight species: Wurdastom bullata , W. cuatrecasasii , W. dorrii , W. dudleyi, W. hexamera, W. lateriflora, W. sneidernii, and W. subglabra. 

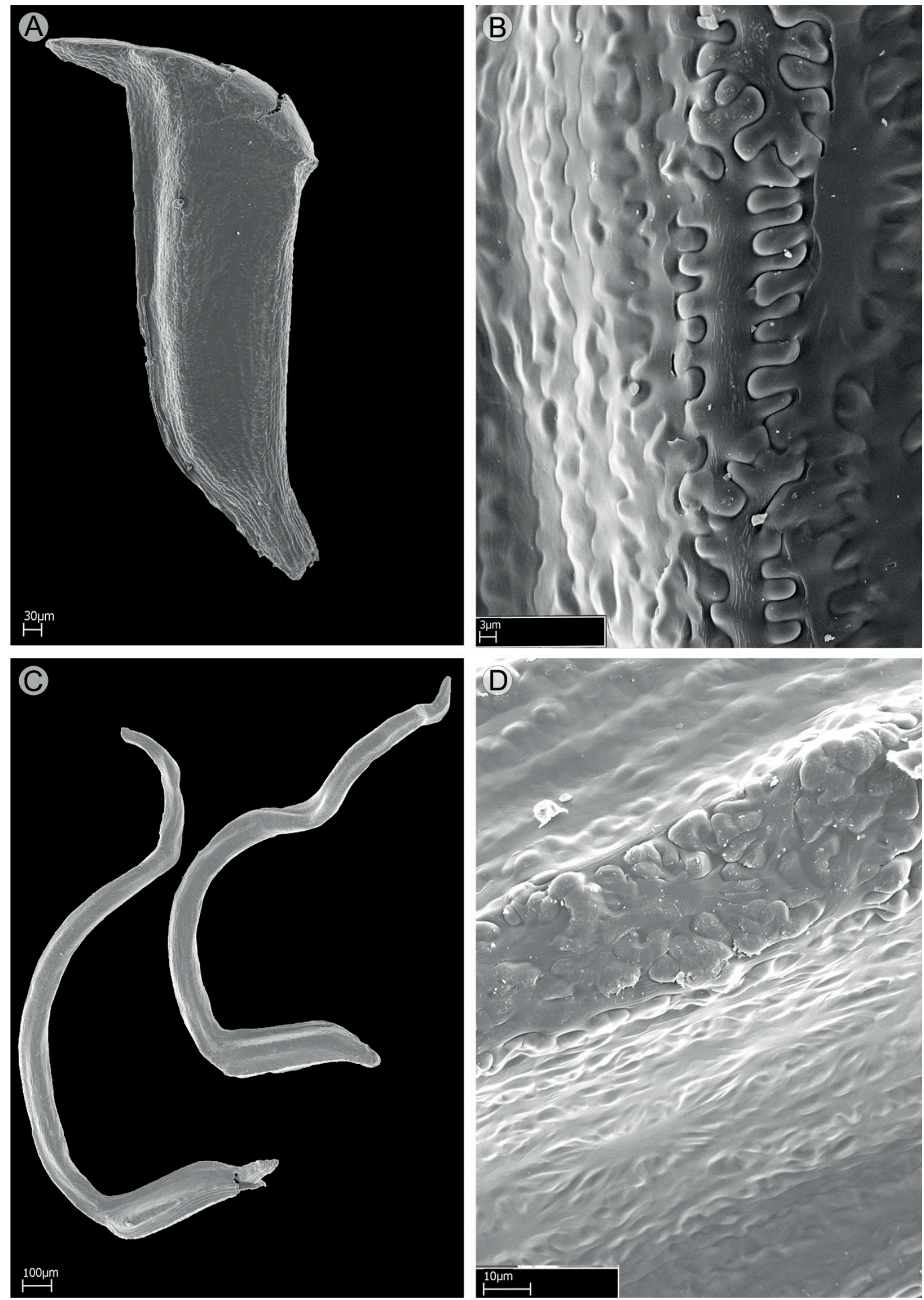

Figure 3: SEM photomicrograph of seeds of Wurdastom B. Walln. Wurdastom bullata (Wurdack) B. Walln.: A. lateral view; B. details of seed testa. Wurdastom sneidernii (Wurdack) B. Walln.: C. lateral view; D. details of seed testa. A, B from Cuatrecasas 22475 (VALLE); C, D from Bradford 3 (QCNE). 

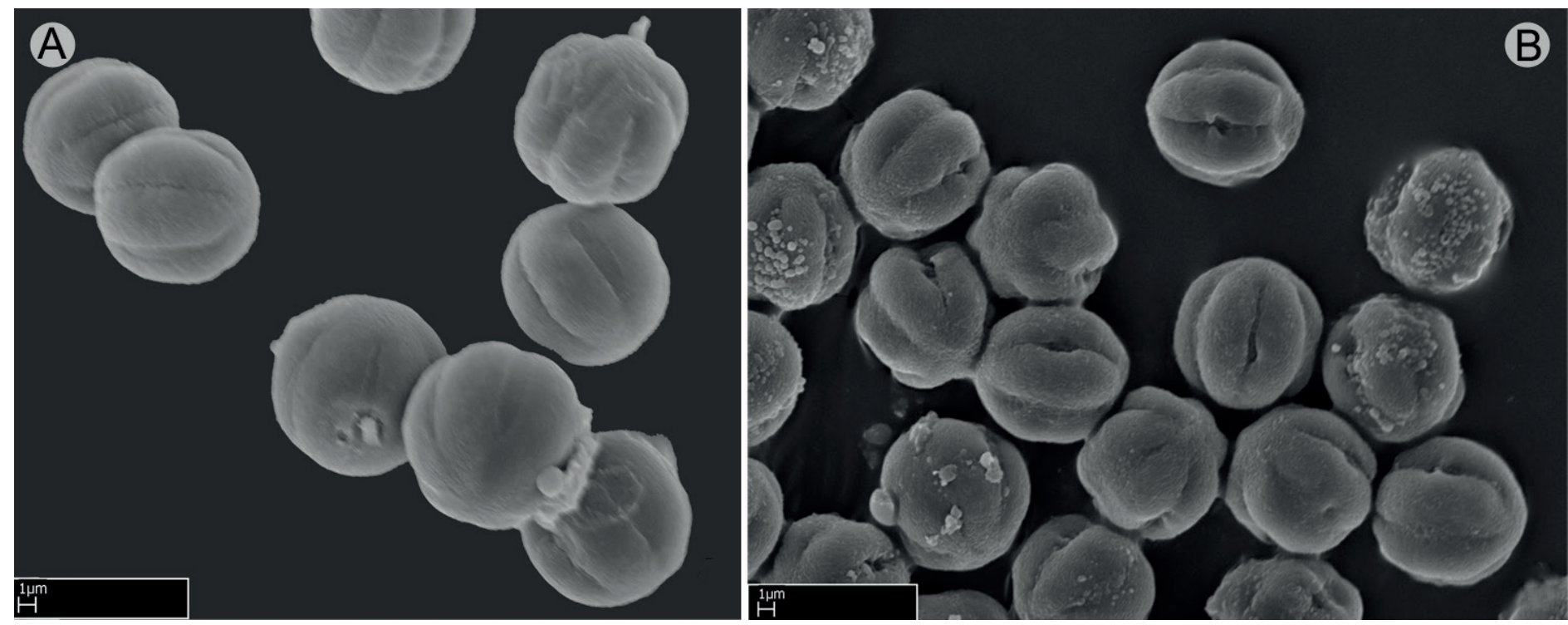

Figure 4: Pollen of Wurdastom B. Walln. A. Wurdastom hexamera (Wurdack) B. Walln.; B. W. sneidernii (Wurdack) B. Walln. A from Almeda 10279 (CAS); B from Díaz 8 (FMB).

Species like $W$. hexamera and $W$. sneidernii can be easily confused with species of Meriania and Graffenrieda due to their calyptrate calyx. The rest of the Wurdastom species can be confused with Miconia Ruiz \& Pav. because they have small flowers in terminal inflorescences. In both cases, it is important to note that Wurdastom has haplostemonous flowers and capsular fruits.

\section{Key to species of Wurdastom}

1a. Upper leaf blade bullate-strigose (with setose trichomes of enlarged base); seeds L-shaped 2

1b. Upper leaf blade smooth or reticulate but not bullatestrigose; seeds pyramidal

2a. Flowers 6-merous; petals pink; regularly with leaf venation slightly plinervate $<0.5 \mathrm{~cm}$ above the base; calyx with short dorsal teeth; plants below 1000 m elevation W. hexamera (Wurdack) B. Walln.

2b. Flowers 7-10-merous; petals white; regularly with leaf venation strongly plinervate $>1 \mathrm{~cm}$ above the base; calyx without dorsal teeth; plants above $1300 \mathrm{~m}$ elevation W. sneidernii (Wurdack) B. Walln.

3a. Plants glabrous; leaf petiole $\leq 4 \mathrm{~mm}$ long W. subglabra (Wurdack) B. Walln. 3b. Plants with evident indumentum of barbellate or appressed trichomes on branchlets, petiole and lower surface of the leaves; leaf petiole $>5 \mathrm{~mm}$ long ........... 4

4a. Upper (adaxial) leaf surface bullate-reticulate, leaf blade widely elliptic .... W. bullata (Wurdack) B. Walln.

4b. Upper (adaxial) leaf surface smooth, leaf blade narrowly elliptic

5a. Lower (abaxial surface) of leaf blade with dense, light ferruginous indumentum covering the whole leaf surface W. dorrii (Wurdack) B. Walln.

5b. Lower (abaxial surface) of leaf blade with sparse indumentum, the actual leaf surface conspicuous and not covered by the hairs

6a. Branchlets, petioles and lower surface of leaf blades with lax indumentum of subsquamiform appressed trichomes; leaf with only one pair of evident secondary veins; inflorescences with unbranched paracladia; plants drying dark brown; Cordillera del Condor in northern Peru and southern Ecuador W. dudleyi (Wurdack) B. Walln.

6b. Branchlets, petioles and lower surface of leaf blade with conic barbellate trichomes appressed or erect; leaves with two pairs of evident secondary veins; in- 
florescences with branched basal paracladia; plants drying green greyish; Cordillera Occidental of Colombia

7a. Inflorescence terminal

W. cuatrecasasii (Wurdack) B. Walln.

7b. Inflorescence lateral ... W. lateriflora Humberto Mend.

Wurdastom bullata (Wurdack) B. Walln., Ann. Naturhist. Mus. Wien 98B(Suppl.): 461. 1996. Fig. 5.

इ Alloneuron bullatum Wurdack, Phytologia 21(6): 362-363. 1971. TYPE: COLOMBIA. Valle del Cauca, Cordillera Occidental, cerro Alto del Mira, between Tabor and Carrizales, 2100-2350 m, 23.X.1946, fl., fr., J. Cuatrecasas 22475 (holotype: $F$ !; isotypes: F!, NY, US!, VALLE!).

Trees, upper internodes subquadrangular terete in older basal parts; branchlets, petioles and inflorescences densely to semidensely covered with short conical clear maroon elongated smooth appressed or erect trichomes, 0.4-1.3 mm long (type 11); petioles $1.5-3 \mathrm{~cm}$ long and 2-2.5 $\mathrm{mm}$ in diameter, terete toward the middle; leaf blades 9-15.5 × 5-11.5 cm, widely elliptic, coriaceous, apex obtuse to acute, base obtuse, margin entire, bullate setulose above (setules ca. $0.2 \mathrm{~mm}$ long, deciduous), or roughened reticulate in old leaves, sparse setulose on the veins below, robust barbellate trichomes, $0.05-0.2 \mathrm{~mm}$ long, venation with 2 pairs of veins arranged laterally to the middle veins, the upper pair plinerved to $0.4-0.7 \mathrm{~cm}$ above the base, 30 42 tertiary veins, separate $2-4 \mathrm{~mm}$, venation impressed above and forming areoles below; inflorescences terminal, pleiothyrsoid, 13-17 cm long, central axis with 5-7 branching nodes, basal paracladia with 2-3 branch orders, flowers sessile and appearing glomerate; flowers 4-5-merous, 3-4 $\mathrm{mm}$ long; hypanthia at anthesis cupuliform, 1.8-1.9 mm long, free portion 0.6-0.8 mm long, appressed setulose externally with short barbellate trichomes, 0.1-0.6 mm long; calyx lobulate, lobes widely triangular, 0.5-0.6 mm long, with subulate external teeth, 0.8-1.0 mm long; petals 2.3$2.5 \times 1.7 \mathrm{~mm}$, obovate, glabrous, rounded to truncate apically; filaments $0.8-1 \mathrm{~mm}$ long, glabrous, apical elbow 0.3 $\mathrm{mm}$ long; anthers oblong, $1 \mathrm{~mm}$ long, with a dorsal oriented pore; ovary 3-locular, 0.9-1.0 mm long; style not seen; capsule 3 valvate, valves ca. 2.5-3.0 mm long, completely opening by valves; seeds numerous, $1 \mathrm{~mm}$ long, pyramidal, with apical chalazal part short and straight.

Common name: on the type specimen the name "nigüito" is given.

Phenology: collected in flower and fruit in October, the dry season in the region.

Habitat and distribution: currently only known from the type locality in Colombia (Fig. 6). It seems to grow above $\mathbf{2 0 0 0 ~} \mathrm{m}$ in the Cordillera Occidental in the Valle del Cauca department. The habitat is located in the Andean forest (Van der Hammen and Rangel-Ch., 1997).

Conservation status: this species is undercollected and the region where the type comes from is unexplored. Considering this, a conservation assessment of Data Deficient (DD) is recommended for W. bullata.

Additional specimens examined: none.

Taxonomic notes: in the herbarium, this species can be confused with Miconia species because of the multiflorous terminal inflorescence and small flowers. Among species of Wurdastom this is the only species with roughened reticulate upper leaf blades.

Wurdastom cuatrecasasii (Wurdack) B. Walln., Ann. Naturhist. Mus. Wien 98B(Suppl.): 461. 1996. Fig. 7.

इ Alloneuron cuatrecasasii Wurdack, Phytologia 21(6): 362. 1971. TYPE: COLOMBIA. Valle de Cauca, western slope of the Cordillera Occidental, river pit Sanjuniquin, left side, La Laguna, 1250-1400 m, 10-20.XII.1943, fl., fr., J. Cuatrecasas 15565 (holotype: F!; isotypes: NY!, US!, VALLE!).

Trees, 4-8 m; upper internodes subquadrangular, terete in older basal parts; branchlets, petioles, inflorescences, hypanthia, ovaries and veins of the abaxial surfaces of leaf blades with densely or semidensely indumentum composed of conic rigid barbellate trichomes, $0.2-0.7 \mathrm{~mm}$ long, slightly 

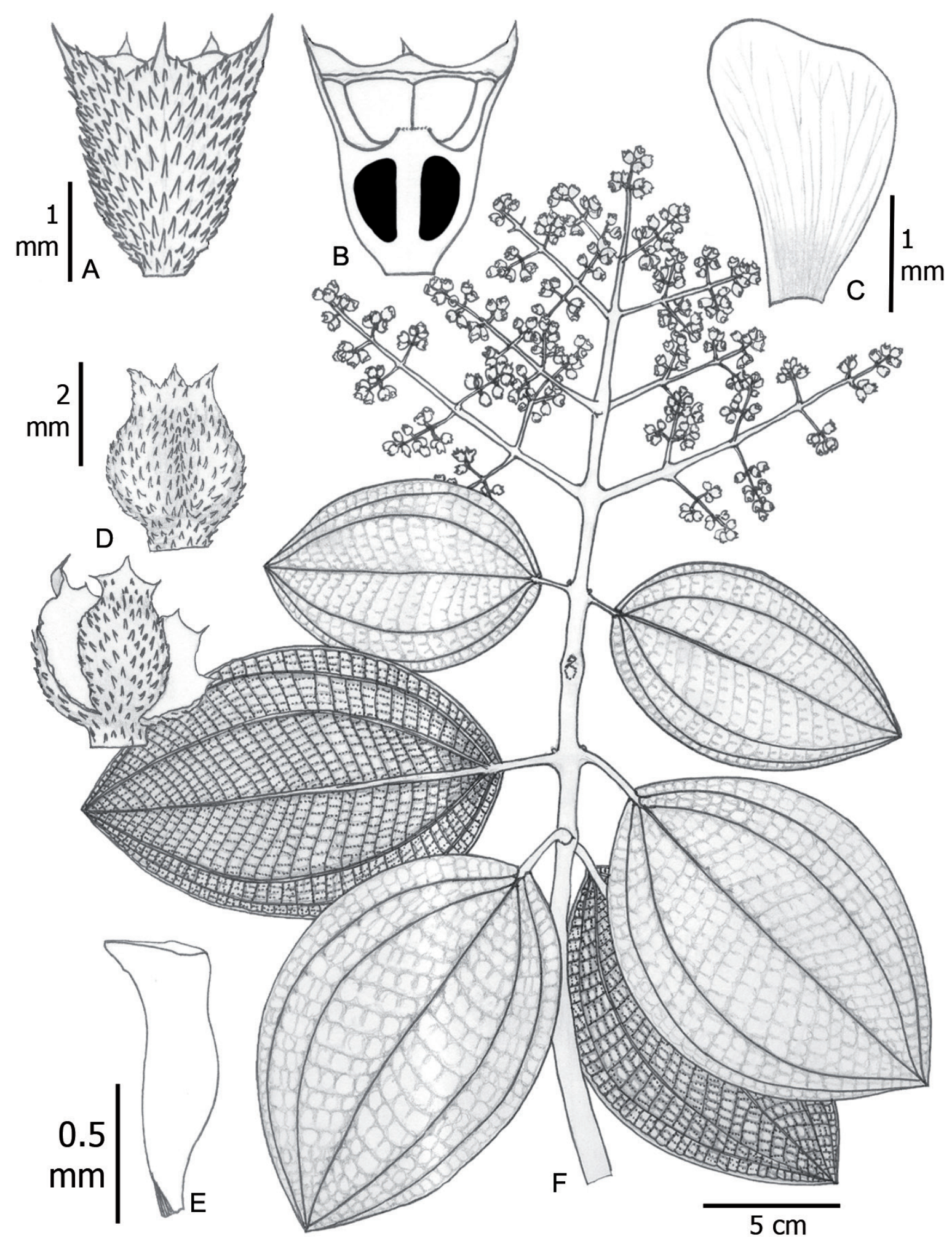

Figure 5: Wurdastom bullata (Wurdack) B. Walln. A. lateral view of hypanthium and calyx; B. longitudinal section of hypanthium, calyx and ovary; C. petal; D. closed and opening capsule; E. seed; F. flowering branch. Drawn from Cuatrecasas 15764 (VALLE). Line drawing by H. Mendoza-Cifuentes. 


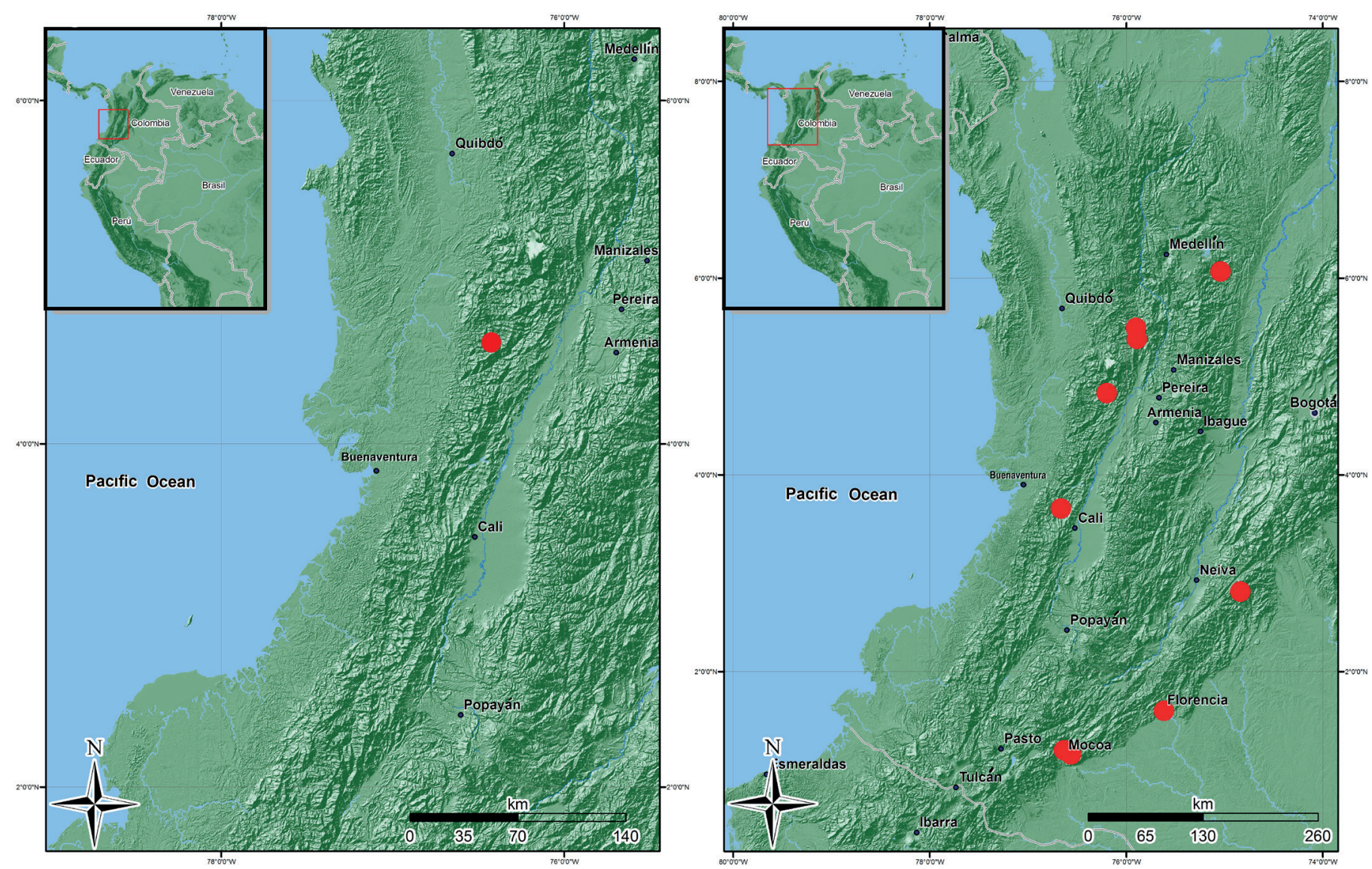

Figure 6: Distribution maps of Wurdastom B. Walln. species. A. Wurdastom bullata (Wurdack) B. Walln.; B. W. cuatrecasasii (Wurdack) B. Walln.

appressed (type 19); petioles 1-1.7 cm long and $2.5 \mathrm{~mm}$ diameter, abaxially canaliculate; leaf blades $12-21.5 \times$ 4.5-9.7 $\mathrm{cm}$, elliptic to ovate-elliptic, thin and rigid, apex acuminate or gradually acute, base acute to strongly attenuate, margin entire; glabrous above, puberulous on the veins below, with dendritic short and few terete armed trichomes 0.05-0.1 mm long (type 25); venation with 2 pairs of veins arranged laterally to the middle veins, the upper pair plinerved to 2.3-4 $\mathrm{cm}$ above the base, 40-50 tertiary veins, separated 2-5 mm; inflorescences terminal, pleiothyrsoid, $11-14 \mathrm{~cm}$ long, central axis with 3-4 branching nodes, basal paraclades with 4 branch orders, nearly $9 \mathrm{~cm}$ long or regularly of similar length to the central axis; flowers 4-5-merous, $3.5 \mathrm{~mm}$ long, sessile; hypanthium at anthesis cupuliform, 1.6-1.8 mm long, free portion 0.6-0.7 $\mathrm{mm}$ long, internally with a pustulate surface, externally with a pubescence of conical barbellate trichomes; calyx lobulate, lobes widely triangular, 0.2-0.3 mm long; petals 1.1-2.3 $\times 0.8-1 \mathrm{~mm}$, obovate to narrowly elliptic, glabrous, white; apex acute to acuminate; filaments 1.4-1.6 $\mathrm{mm}$ long, flattened, glabrous, apical elbow 0.5-0.7 × 0.5-0.7 $\mathrm{mm}$; anthers oblong to oblong-obovate, $1.0 \mathrm{~mm}$ long, with a dorsal oriented pore; ovary 2-3-locular, 0.8-1.1 mm long, placenta obovate, $0.36 \mathrm{~mm}$ long; styles 3-3.2 mm long, pentagonal-aristate toward the base, terete toward apices, slightly curved in the middle superior part in open flowers; capsule 1.8-2.2 $\mathrm{mm}$ long, opening into three papyraceous valves; seeds abundant, 0.7-0.8 mm long, cuneiform with the apical chalazal part short and straight.

Phenology: collected with flowers in the Putumayo department in October. The type from Valle del Cauca, which has flowers and fruits, was collected in December. The months where flowering is reported coincide with the periods of lowest rainfall in the Andean region of Colombia. 


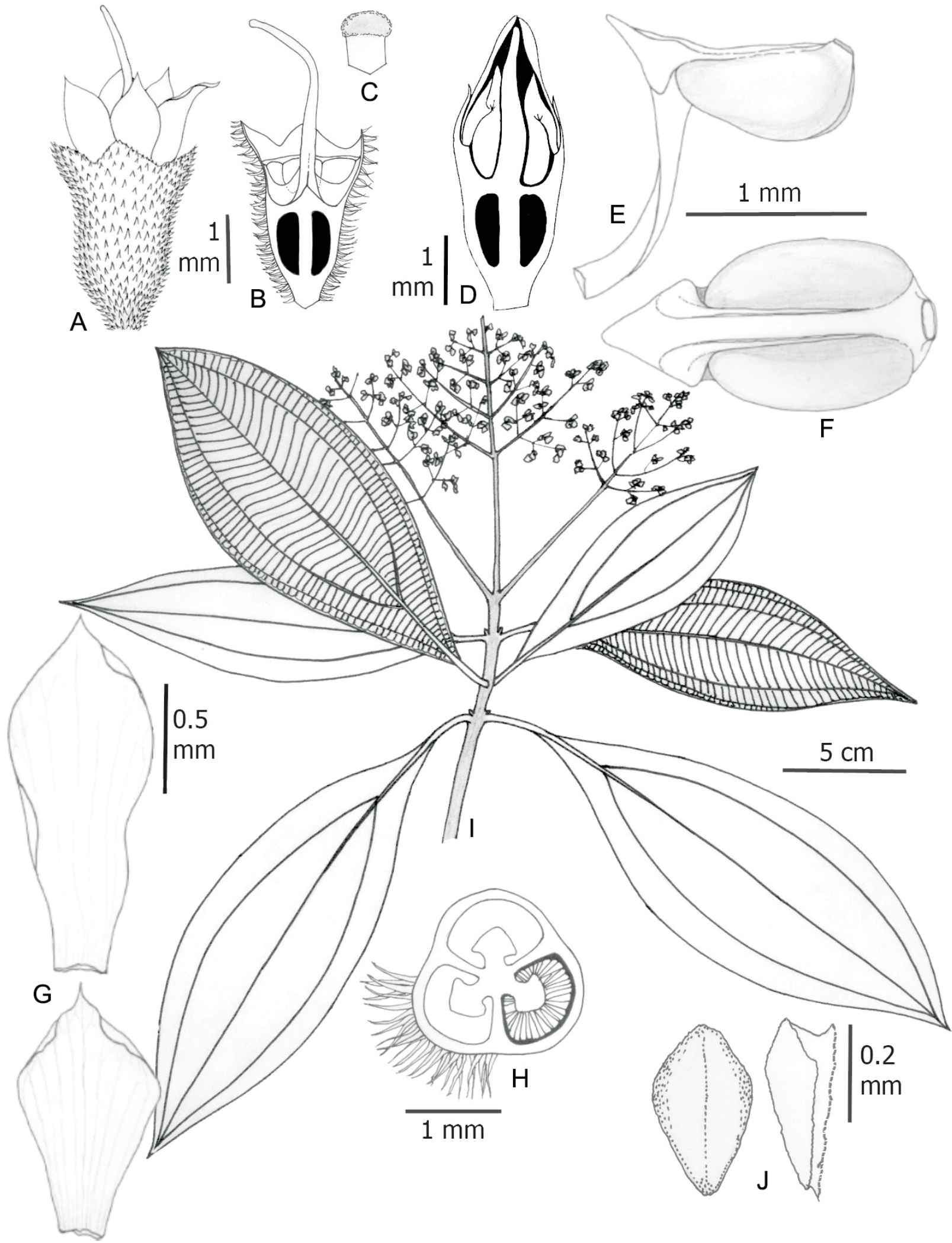

Figure 7: Wurdastom cuatrecasasii (Wurdack) B. Walln. A. lateral view of hypanthium and calyx; B. longitudinal section of hypanthium, calyx and ovary; C. stigma; D. longitudinal section of a floral bud prior to anthesis; E, F. stamen in lateral and dorsal views; G. petals; H. horizontal section of hypanthium, ovary; I. flowering branch; J. placenta in dorsal (left) and lateral (right) view. A-I from García 06 (FMB). Line drawing by H. MendozaCifuentes. 
Habitat and distribution: this species is restricted to Colombia on the western slope of the Western Cordillera, north of the Central Cordillera and some localities in the foothills of the Colombian Massif in the departments of Antioquia, Caquetá, Cauca, Choco, Putumayo, Risaralda, and Valle del Cauca, between 1200-2537 m (Fig. 6). It grows inside forests in the vegetational fringe of Andean and subandean forests.

Conservation status: the area of ocupancy for this species is less than $24,000 \mathrm{~km}^{2}$, and restricted to undisturbed subandean and Andean forests, so I suggest an assessment of Endangered (EN). However, I recommend an alternative status of Vulnerable (VU-B1a), considering that in the western slope of the Cordillera Occidental there are still relicts of forest in good condition and in the southern region of the distribution there is a new conservation area (Serranía Los Churumbelos, department of Putumayo).

Additional specimens examined: COLOMBIA. Antioquia, San Luis, vereda Manizales, 1642 m, 25.X.2012, fr., D. Suescún 1180 (HUA); Andes, vereda La Mecenia, Fundation Colibrí, 2537 m, 23.VI.2009, st., A. Taborda 94 (HUA). Caquetá, Florencia, road Florencia - Suaza km 47, La Esperanza, 2000-2150 m, 136' N, 75³7' W, 17-20.IX.1993, fl., fr., J. G. Ramírez 5147 (COAH, JAUM), 5158 (COAH, JAUM), 5168 (COAH, JAUM), 5345 (COAH, JAUM); San Vicente del Caguán, river basin Pato, $1400 \mathrm{~m}, 2^{\circ} 48^{\prime} 49^{\prime \prime} \mathrm{N}, 74^{\circ} 50^{\prime} 19^{\prime \prime} \mathrm{W}$, 20.XI.1997, st., H. Mendoza 4017 (FMB), 4012 (FMB), 4537 (FMB). Chocó, San José del Palmar, old school of Galápagos, 1300-1600 m, 26.V.2008, fr., H. Mendoza 17348 (FMB). Putumayo, Medio Afán, 26.VII.1990, fl., L. García 06 (CUVC); Mocoa, corregimiento San Antonio, vereda Alto Campucana, farm La Mariposa, $1350 \mathrm{~m}, 1^{\circ} 12^{\prime} \mathrm{N}, 76^{\circ} 38^{\prime} \mathrm{W}$, 20.V.1994, fl., P. Franco 5288 (COL). Risaralda, Mistrató, 1600-1650 m, 21.V.1992, fl., J. Fernández-Alonso 9870 (COL, HUA).

Taxonomic notes: this species can be easily recognized by its strongly plinerved leaf blades, indumentum of barbellate trichomes on vegetative parts, and terminal inflorescences; there are no other species of Melastomataceae in Colombia with these characteristics. When in flow- er it may be confused with Miconia, and in fruit it may be mistaken for a species of Graffenrieda.

Wurdastom dorrii (Wurdack) B. Walln., Ann. Naturhist. Mus. Wien 98B(Suppl.): 461. 1996. Fig. 8.

三 Alloneuron dorrii Wurdack, Phytologia 69(5): 323-324. 1990. TYPE: ECUADOR. Zamora-Chinchipe, new road to Zamora, banks of Río Zamora ca. 25 km east of Loja, 2090 m, $4^{\circ} 00$ 'S, 79¹3'W, 11.VII.1989, fl., L. J. Dorr 6604 (holotype: NY!; isotypes: CAS!, GB, S!, US!).

Erect shrubs, 4-5 m, upper internodes subquadrangular; branchlets densely covered with amorphous appressed trichomes; inflorescence axes and petioles densely covered with minute, short conic dendritic trichomes, ca. $0.3 \mathrm{~mm}$ long (type 25); petioles $1-1.65 \mathrm{~cm}$ long, abaxially slightly canaliculate toward middle part; leaf blades 7-12 × 2-4.5 $\mathrm{cm}$, elliptic, thin and rigid, apex acute, base acute, margin entire, glabrous and slightly roughened above, below with a dense light ferruginous indumentum composed of barbellate trichomes, $0.5 \mathrm{~mm}$ long (type 19), venation with 2 pairs of veins arranged laterally to the middle veins, the upper pair plinerved to $0.4-1 \mathrm{~cm}$ above the base; $45-52$ tertiary veins, separated 2-3 mm; inflorescences terminal, pleiothyrsoid, 8-11 cm long, central axes with 5-7 branching nodes, basal paracladia with 2-3 branch orders; flowers sessile and appearing glomerate; flowers 5-merous, 4-5 mm long; hypanthia at anthesis cupuliform, 2-2.3 mm long, free portion 0.6-0.7 mm long, externally with a dense indumentum of appressed setulose trichomes, 0.2-0.3 mm long; calyx lobulate, lobes widely triangular, $0.4 \mathrm{~mm}$ long, external teeth narrow triangular and slightly longer than the lobules; petals 2.6$2.7 \times 1.4-1.5 \mathrm{~mm}$, oblong obovate, subglabrate, white, apex acute; filaments 2-2.3 mm long, apical elbow 0.4-0.6 0.4 $\mathrm{mm}$; anthers oblong, 1.4-1.7 mm long, with a dorsal oriented pore; ovary 3-locular, 1.1-1.2 mm long, apex projected 0.1 $\mathrm{mm}$ long, with 5 winged appendages that are fused with the internal partition walls of the hypanthium, placenta narrowly obovate; styles $6.0 \mathrm{~mm}$ long, straight, glabrous; stigmas slightly expanded, $0.2 \mathrm{~mm}$ in diameter, papillose; capsules 3-3.2 mm long; seeds abundant, 0.8-1 mm long, cuneiform and with an apical chalazal part that is short and straight. 


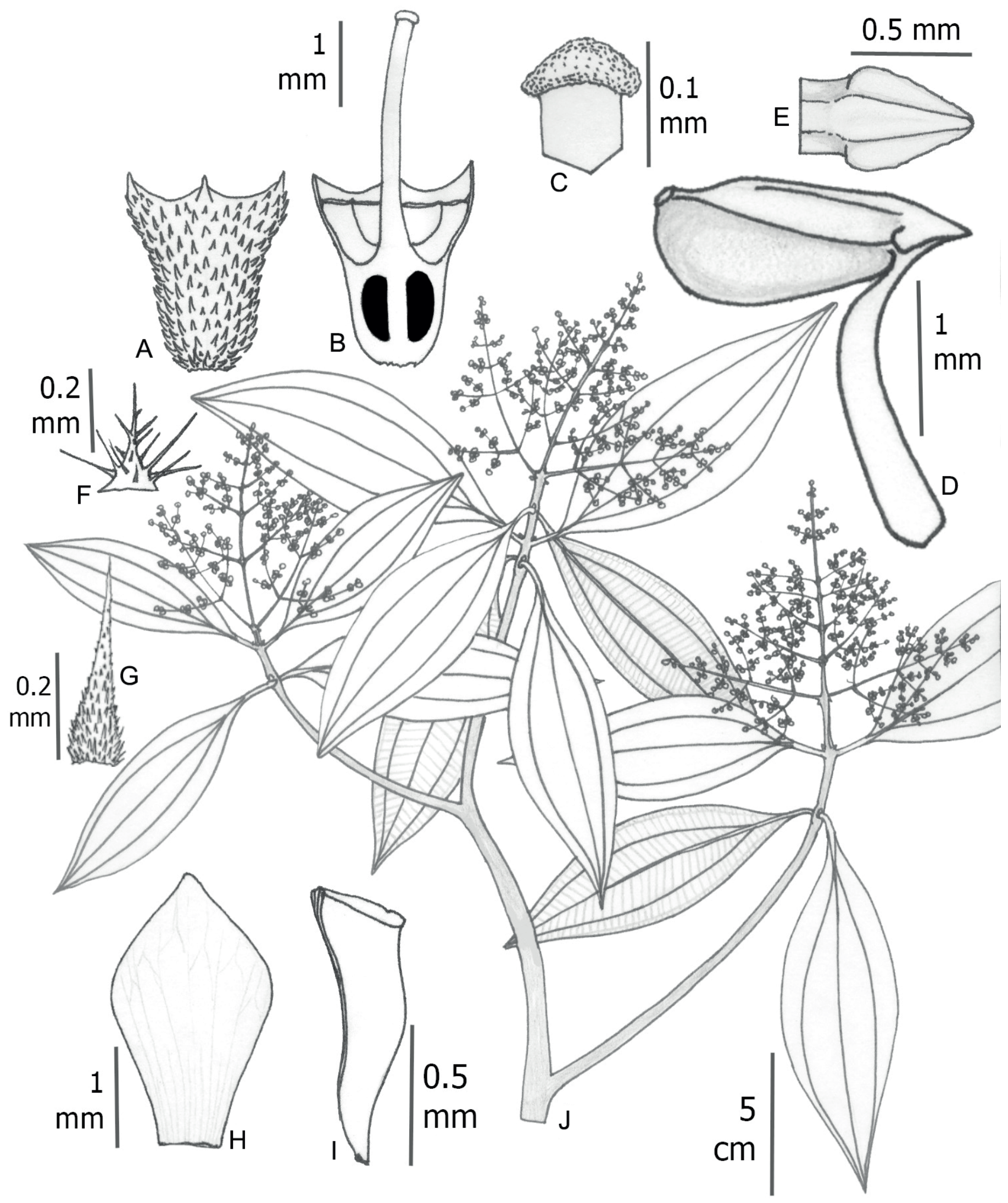

Figure 8: Wurdastom dorrii (Wurdack) B. Walln. A. lateral view of hypanthium and calyx; B. longitudinal section of hypanthium, calyx, ovary and style; C. stigma; D. stamen; E. elbow (stamen) in dorsal view; F. trichome of abaxial leaf surface; G. hypanthial trichome; H. petal; I. seed; J. flowering branch. A-J from Dorr 6604 (CAS). Line drawing by H. Mendoza-Cifuentes. 
Phenology: the type was collected in flower in July during the rainy season.

Habitat and distribution: currently only known from the type locality in Ecuador (Fig. 9). Based on the classificaton of Van der Hammen and Rangel-Ch. (1997), its habitat is Andean forest.

Conservation status: because this species is undercollected and known only from the type collection: I recommend a conservation status of Data Deficient (DD).

Additional specimens examined: none.

Taxonomic notes: this species is easily recognized by the dense light ferruginous indumentum on the abaxial leaf surface. Wurdastom cuatrecasasii is similar but does not have the ferruginous indumentum on abaxial leaf surfaces.
Wurdastom dudleyi (Wurdack) B. Walln., Ann. Naturhist. Mus. Wien 98B(Suppl.): 461.1996. Fig. 10.

三 Alloneuron dudleyi Wurdack, Phytologia 21(6): 363-364. 1971. TYPE: PERU. Cuzco, province Convención, cloud forest in full sun at Camp 21/2 on the east side of the Río Apurimac across from the Hacienda Luisiana, Cordillera Vilcabamba, $12^{\circ} 38^{\prime} \mathrm{S}, 73^{\circ} 38^{\prime} \mathrm{W}, 1730 \mathrm{~m}$, 20.VI.1970, fl., M. T. Madison 10101 (holotype: US!).

Trees, 4-8 m, upper internodes subquadrangular; young branchlets, petioles and inflorescence peduncles laxly covered with a mixture of rufous subsquamiform barbellate and appressed trichomes, 0.2-1 mm long, and roughened amorphous trichomes, terminal parts of the inflorescence with a lax indumentum of conic barbellate trichomes (type 19); petiole $0.5-3 \mathrm{~cm}$ long, abaxially canaliculate toward the middle part; leaf blades 7-19.5 × 2-6.5 cm, elliptic
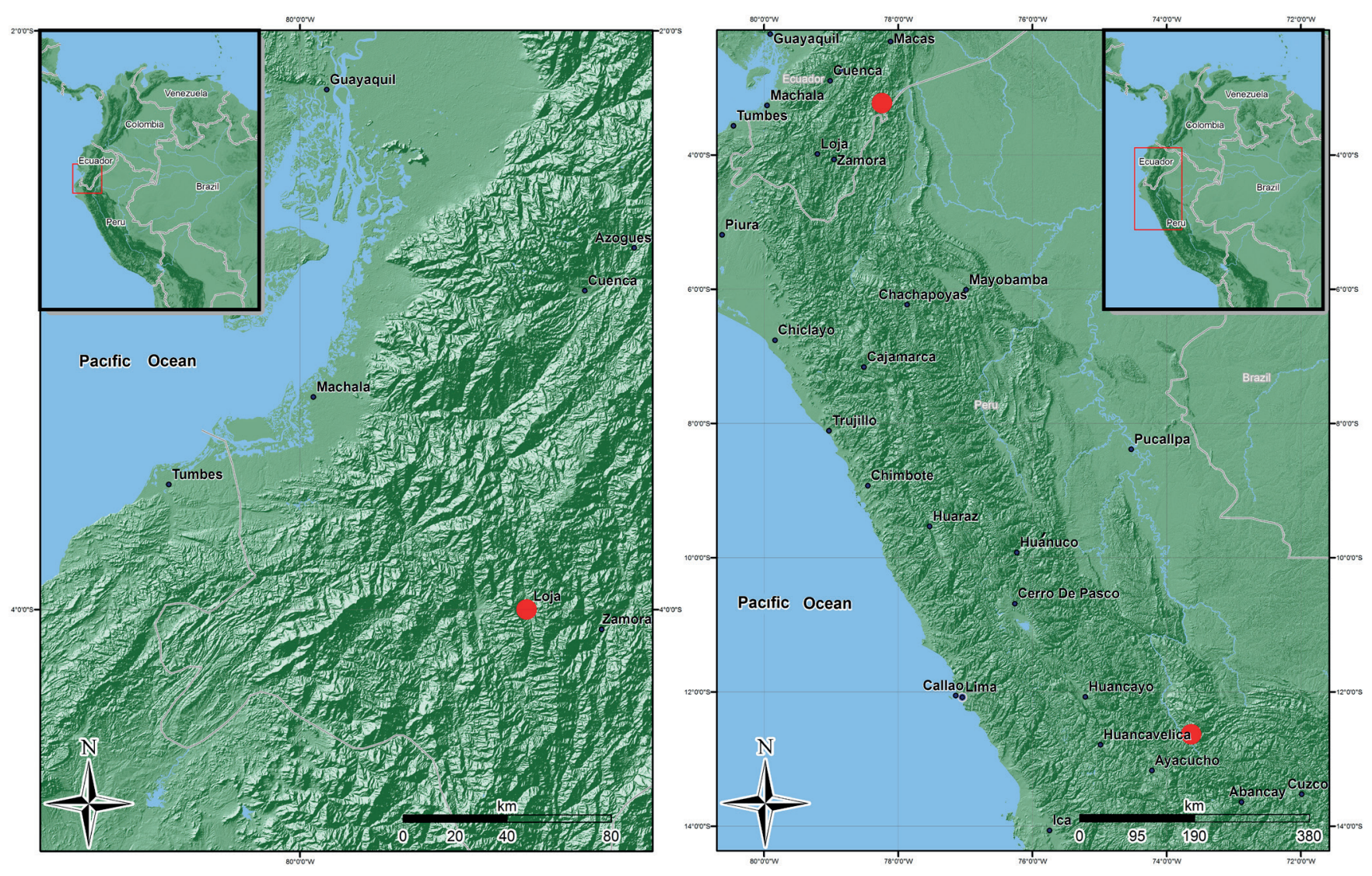

Figure 9: Distribution maps of Wurdastom B. Walln. species. A. Wurdastom dorri (Wurdack) B. Walln.; B. W. dudleyi (Wurdack) B. Walln. 


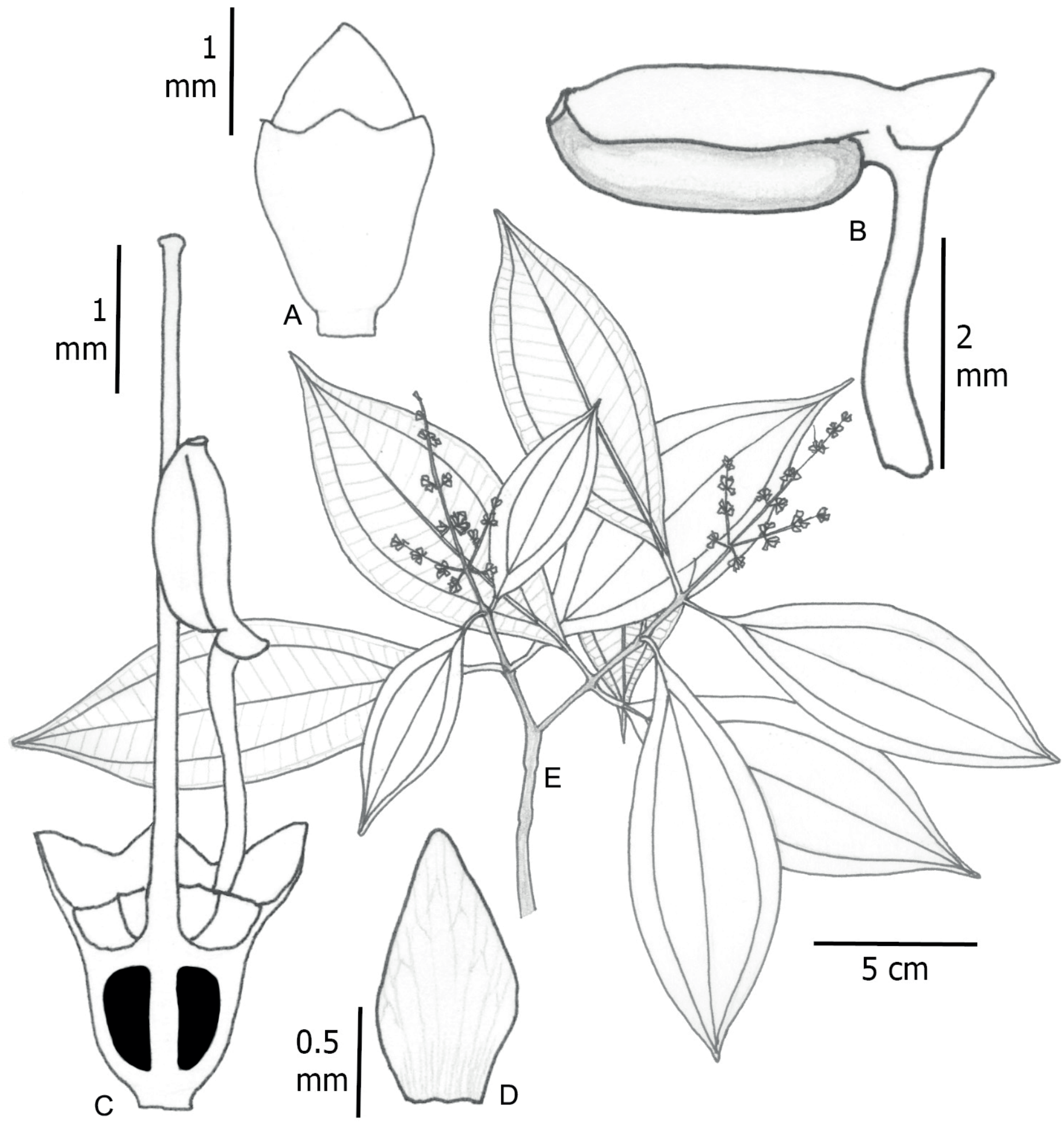

Figure 10: Wurdastom dudleyi (Wurdack) B. Walln. A. lateral view of bud; B. stamen; C. longitudinal section of hypanthium, calyx, ovary and style with stamen; D. petal; E. flowering branch. A-E from Katan 52 (QCNE). Line drawing by H. Mendoza-Cifuentes. 
to elliptic-lanceolate, thin and rigid; apex acuminate, base acute to attenuate, margin entire, glabrous above, sparse indumentum of short barbellate trichomes below, on venation the trichomes are subsquamiform and appressed; venation with one pair of veins arranged laterally to the middle veins and one additional pair near the margins but not reaching the leaf apex, the upper pair plinerved to $1-3.5 \mathrm{~cm}$ above the base, 22-40 tertiary veins, separated $2.5-5 \mathrm{~mm}$; inflorescences terminal, thyrsoid, 7-10 cm long, short branched; peduncles 1-3.5 cm long, central axis with 5-7 branching nodes, basal paracladia 2-5.3 cm long, with 1 branch order, flowers sessile in very short helicoid twigs; flowers 4-6-merous, 3-4 mm long; hypanthia at anthesis cupuliform, $2.4 \mathrm{~mm}$ long, free portion $0.3 \mathrm{~mm}$ long; externally with a dense indumentum of conic barbellate trichomes, 0.4-1 mm long, calyx subcalyptrate, $0.6 \mathrm{~mm}$ long, with triangular to obtuse lobes of 0.3-0.4 mm long, without external teeth; petals 1.2$1.3 \times 0.6-0.9 \mathrm{~mm}$, narrowly triangular, glabrous, white, apex acute; filaments 0.4-0.6 mm long, apical elbow 0.3-0.4 mm long; anthers obovate or oblong, 0.9-1 $\times$ 0.5-0.6 mm, with a dorsal pore; ovary 3-locular, 0.7-0.8 mm long; styles 4-5 mm long, cylindrical, basally slightly aristate, glabrous, straight in open flowers, stigmas slightly expanded, papillose; capsules not seen; seeds numerous, $0.7 \mathrm{~mm}$ long, cuneiform and with apical chalazal part short and straight.

Phenology: flowering in June.

Habitat and distribution: known from type locality in central Peru and a second locality in the territory of the native Shuar community in southern Ecuador (Fig. 9). The two localities are in the Cordillera del Cóndor (Ecuador) and Cordillera de Vilcabamba (Peru) on the Amazonian side of the Andes between 1490-1730 m.

Conservation status: although this species is restricted to two localities separated by a distance of nearly 1200 $\mathrm{km}$, and with a area of ocupancy less than $8000 \mathrm{~km}^{2}$, it is possible that it is distributed along the Amazonian slope of the Andes between central Peru and southern Ecuador where there are some conservation areas. Considering this, I suggest a conservation assessment of Vulnerable (VUB1iii).
Additional specimens examined: ECUADOR. Morona Santiago, Limón Indaza Cantón, Cordillera del Cóndor, Centro Shuar Warints, cerro Chankinnaint, bosque con árboles

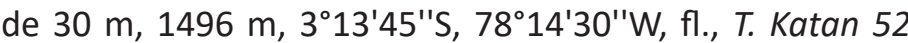
(QCNE).

Taxonomic notes: the species that are most similar to $W$. dudleyi are W. cuatrecasasii and W. dorri, but W. dudleyi differs from these by their leaves that dry black, lax indumentum of appressed trichomes, only one pair of evident secondary veins, and inflorescences with non-branched paracladia. Another similar species is $W$. lateriflora, but they differ in the number of secondary veins on the leaves and the position and type of inflorescences. Superficially, it can be confused with Miconia, but it differs in stamen morphology and the haplostemonous flowers.

Wurdastom hexamera (Wurdack) B. Walln., Ann. Naturhist. Mus. Wien 98B(Suppl.): 461. 1996. Figs. 11, 12.

三 Alloneuron hexamerum Wurdack, Phytologia 21(6): 148149. 1974. TYPE: COLOMBIA. Cauca, El Tambo, in silva primaeva ad La Costa, 800 m, 17.III.1938, fl., K. von Sneidern 1638 (holotype: $\mathrm{S}$, digital image!).

Shrubs or trees, 3-7 m, upper internodes subquadrangular; branches, petioles and inflorescences densely covered with conic barbellate trichomes 1-1.4 mm long (type 19); petioles 3-11.5 cm long, terete; leaf blades $12-24 \times 8-14 \mathrm{~cm}$, oblong ovate, membranaceous, apex acuminate, drip tips 1-2 cm long, base rounded, margin serrate, bullate-strigulose above, with bulla-based trichomes without enations, 0.5-0.9 $\mathrm{mm}$ long (type 15), abaxial surface with indumentum on the veins similar to the branchlets and inflorescences; venation with 3-4 pairs of secondary veins arranged laterally to the middle vein, the inner pair basal or slightly plinerved; inflorescences terminal, pleiothyrsoid, $10-27 \mathrm{~cm}$ long, central axis with 5-7 branching nodes, peduncle 3-7 cm long; basal paracladia 7-16 cm long, with 3 branch orders, flowers sessile or subsessile; flowers 6-merous, 8-9 mm long; hypanthia at anthesis cupuliform, 5-5.6 mm long, free portion 1.7-2.3 $\mathrm{mm}$ long, externally with a dense indumentum of large elongated slightly roughened trichomes, 0.7-1.3 mm long, short 


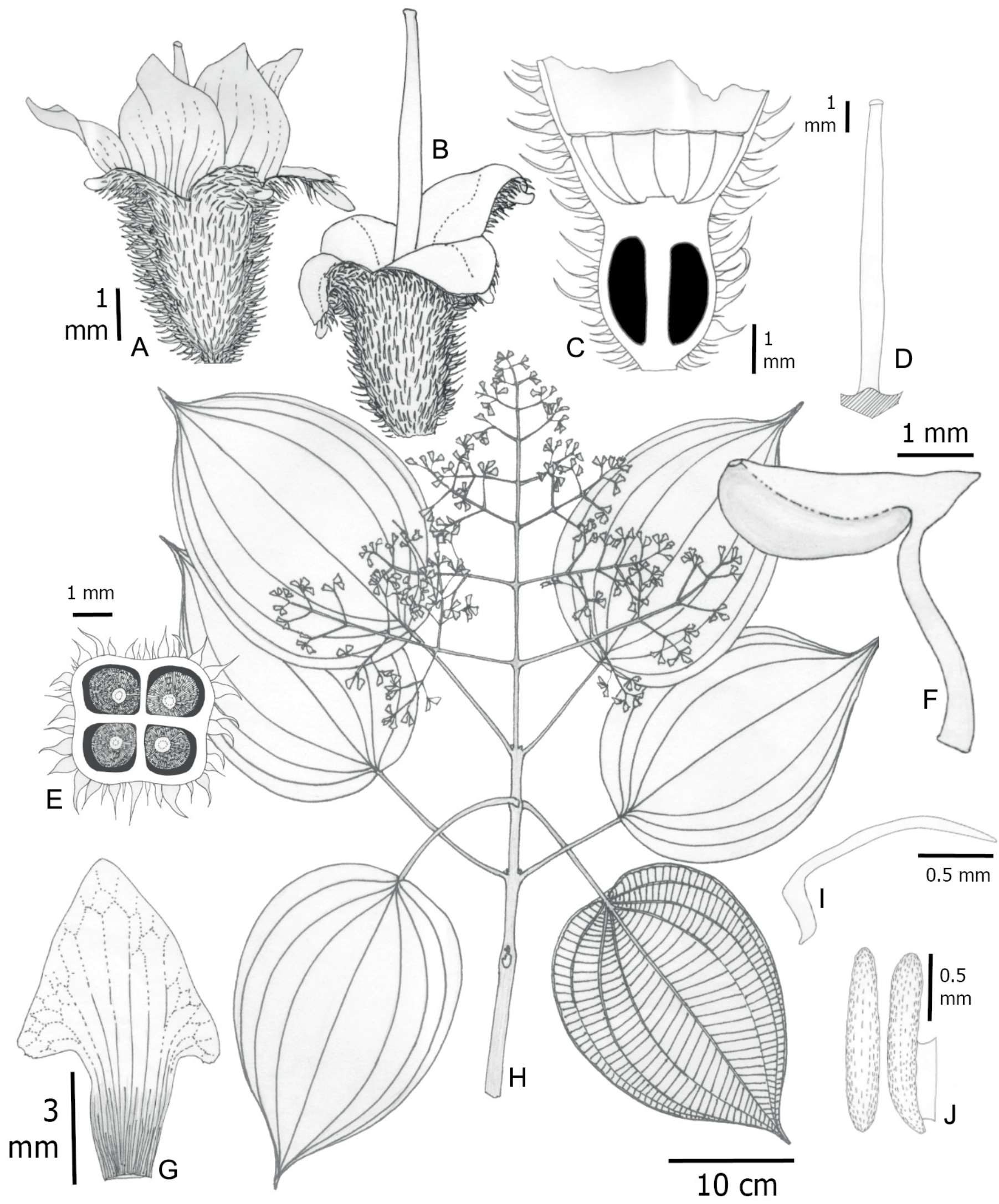

Figure 11: Wurdastom hexamera (Wurdack) B. Walln. A. flower in lateral view; B. hypanthium, calyx and style in lateral view; C. longitudinal section of hypanthium, calyx and ovary; D. style; E. horizontal section of hypanthium and ovary; F. stamen; G. petal; H. flowering branch; I. seed; J. placenta in dorsal (left) and lateral (right) view. A-J from Almeda 10279 (CAS). Line drawing by H. Mendoza-Cifuentes. 

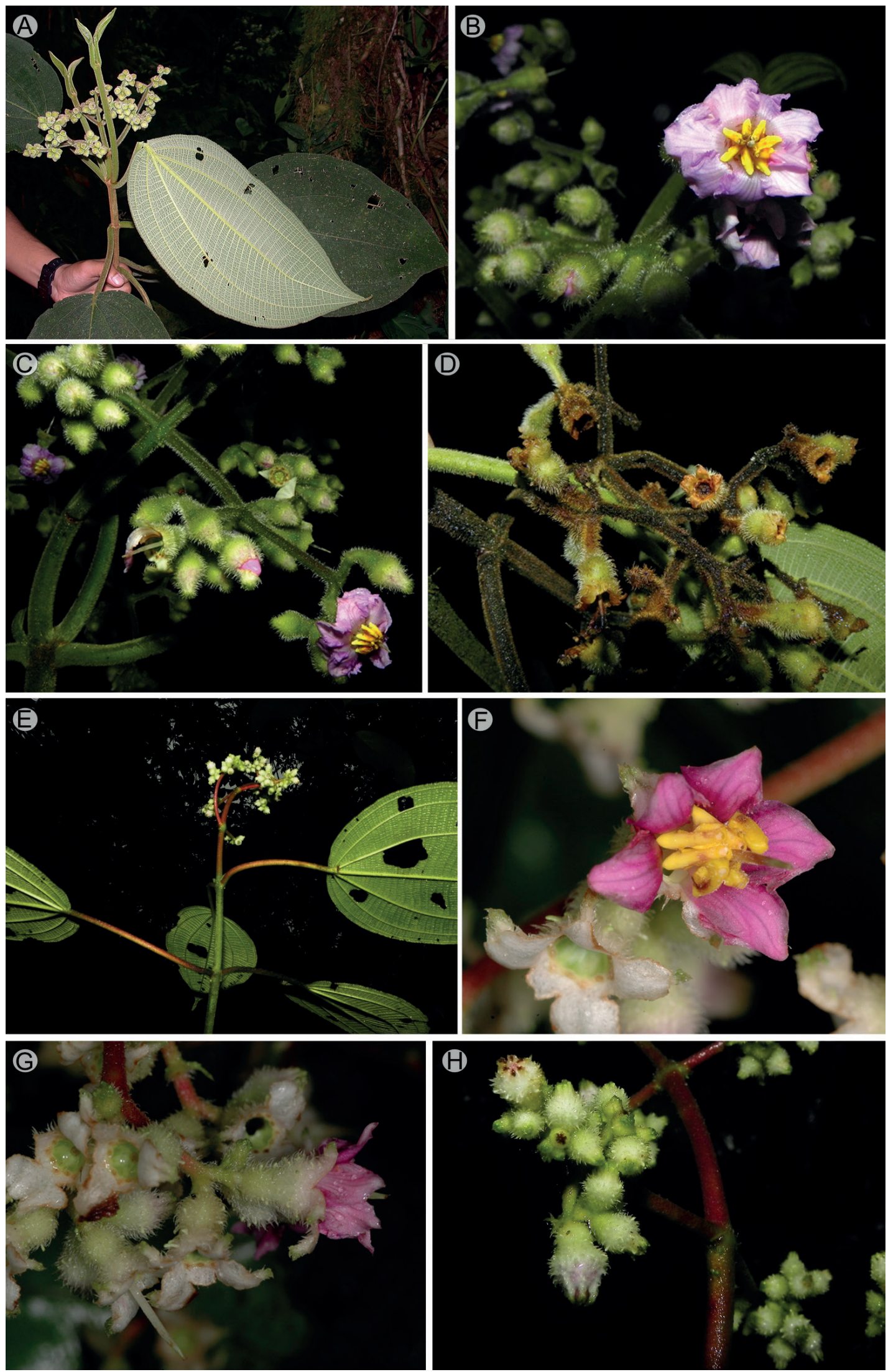

Figure 12: Field images of Wurdastom B. Walln. Wurdastom sneidernii (Wurdack) B. Walln.: A-D: A. branch with flowers; B, C. inflorescences and flowers, D. capsules; W. hexamera (Wurdack) B. Walln.: E-H: E. branch with flowers; F. flower in top view, G. flowers in lateral view, H. flowers buds. A. from La Planada in Nariño, Colombia (Instituto Alexander von Humboldt); B-F. from PNN Munchique and Anchicayá, Colombia (A-E, H by M. Alvear; F-G by F. Almeda). 
trichomes, 0.2-0.3 mm long; calyx calyptrate and rupturing by irregular caducous lobes, with short dorsal teeth, externally with indumentum like the hypanthia; petals 4.2-8.3 $\times$ 1.8-4.6 mm, sagitate and with an apiculate apex, dorsally strigulose, pink; filaments $3.0-3.8 \mathrm{~mm}$ long, apical elbow 0.7-0.9 $\times 0.7 \mathrm{~mm}$; anthers oblong, 1.7-2.9 $\mathrm{mm}$ long, with a dorsal oriented pore; ovary 4-locular, 2.5-3.3 mm long, cylindrical, apex projected 0.3-0.4 mm; styles 4.2-9.3 mm long, straight, glabrous, stigmas punctiform or slightly expanded in fresh material, papillose; capsules 4 valvate, with numerous seeds; seeds L-shaped, with a cordiform appendage of $1.3 \times$ $0.05 \mathrm{~mm}$ in the chalazal zone, embryo portion $0.5 \times 0.1 \mathrm{~mm}$.

Phenology: collected in flower from January to March.

Habitat and distribution: only known from two localities in the Cauca and the Valle del Cauca departments in Co- lombia. It grows in the foothills of the Pacific slope of the Cordillera Occidental, between 800-1400 m, in pristine subandean and tropical humid forest (Fig. 13).

Conservation status: this species is undercollected and there is insufficient information to calculate $\mathrm{AOO}$ and EOO values. Therefore, I consider its conservation status as Data Deficient (DD).

Additional specimens examined: COLOMBIA. Cauca, El Tambo, La Costa, 8.III.1936, fr., K. von Sneidern 977 (paratype, S). Valle del Cauca, municipio Dagua, Corregimiento EI Queremal, PNN Farallones de Cali, sector Alto Anchicayá, trail of (upslope) quebrada La Riqueza, 650-810 m, 3³5.998' $\mathrm{N}$, 7653.609'W, 6.Il.2011, fl., F. Almeda et al. 10279 (CAS, $\mathrm{COL})$; Corregimiento El Queremal, PNN Farallones de Cali, sector Alto Anchicayá, trail of quebrada La Riqueza, 982 m,
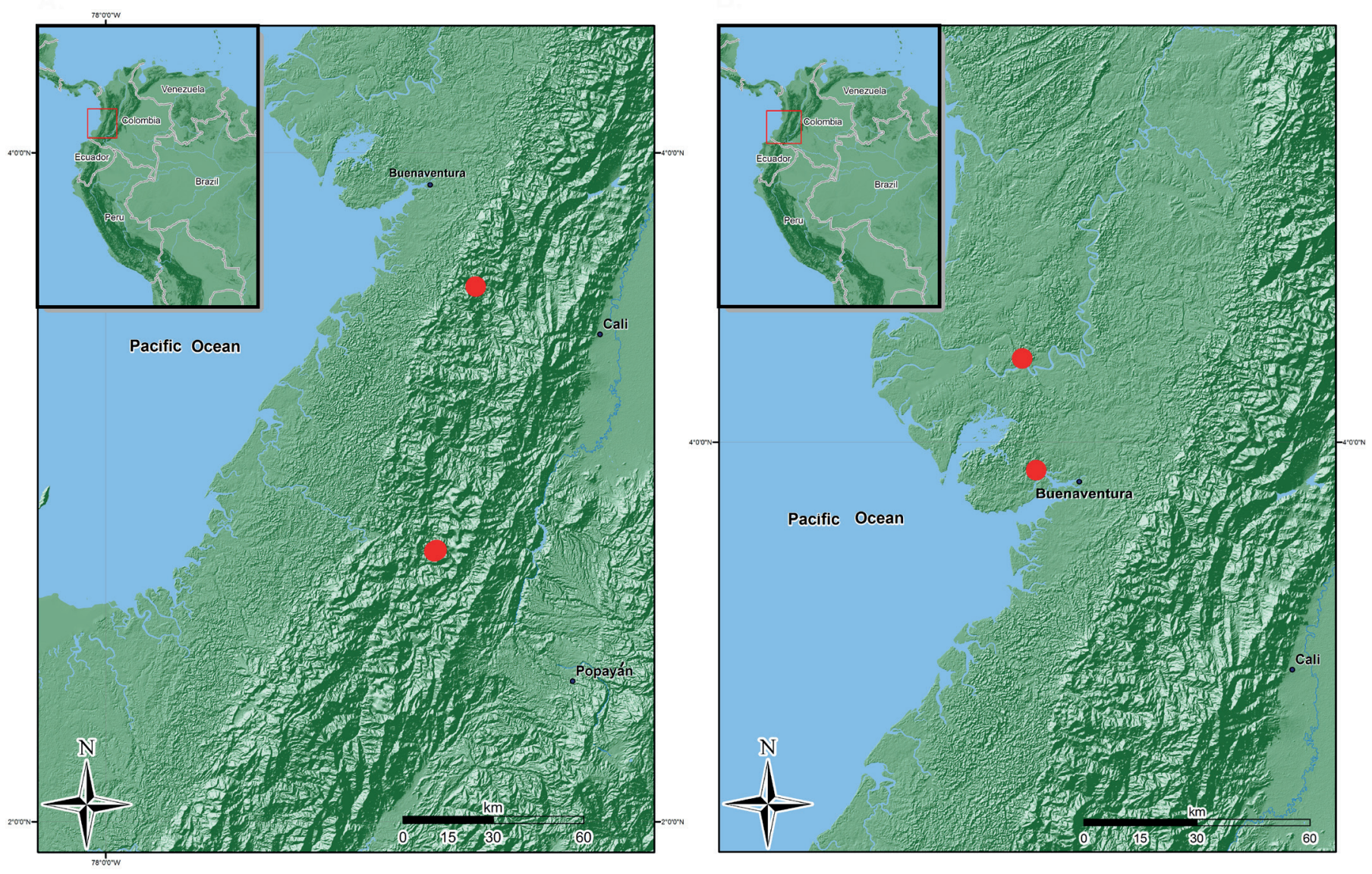

Figure 13: Distribution maps of Wurdastom B. Walln. species. A. Wurdastom hexamera (Wurdack) B. Walln.; B. W. lateriflora Humberto Mend. 
$3^{\circ} 36.108^{\prime} \mathrm{N}, 76^{\circ} 53.865^{\prime} \mathrm{W}, 10.1 .2013, \mathrm{fr} .$, M. Alvear et al. 1556 (CAS, COL); Corregimiento El Queremal, PNN Farallones de Cali, sector Alto Anchicayá, trail La Riqueza, 1193 m, $3^{\circ} 36.078^{\prime} \mathrm{N}, 76^{\circ} 54.078^{\prime} \mathrm{W}, 13.1 .2013$, fr., M. Alvear et al. 1627 (CAS, COL).

Taxonomic notes: most characteristics of the species match W. sneidernii, but differ in the basal or slightly plinerved venation (vs. strongly plinerved in W. sneidernii), smaller flowers (petals less than $8 \mathrm{~mm}$ long, vs. 9-10 mm) and 6-merous flowers (vs. 7-10-merous flowers), and calyx with short dorsal teeth. The elevational distribution of $W$. hexamera is below $1400 \mathrm{~m}$, while in W. sneidernii it is above 1300-1400 m.

Wurdastom Iateriflora Humberto Mend., sp. nov. Fig. 14.

Species affine to Wurdastom cuatrecasasii but differing by the lateral thyrsoid inflorescences and dense indumentum of appressed subulate squamiform trichomes on the internodes, nodes, veins on abaxial leaf surfaces, and inflorescences.

TYPE: COLOMBIA. Valle de Cauca, Bajo Calima, ca. $15 \mathrm{~km} \mathrm{~N}$ of Buenaventura, Cartón Colombia concession, transition between wet and pluvial forest, $500 \mathrm{~m}, 3^{\circ} 56^{\prime} \mathrm{N}$, 7708'W, 27.III.1986, fr., A. Gentry 53710 (holotype: CUVC!; isotype: $\mathrm{MO}$ !).

Erect shrubs or trees, 2-10 m, upper internodes subquadrangular or slightly quadrangular; branchlets, petioles, inflorescences and fruits densely covered with of a mixture of appressed subulate subsquamiform trichomes, 0.2-0.7 $\mathrm{mm}$ long (type 19), and other very large subulate ones, 1-2.1 mm long (type 16); petioles 1.1-2.3 cm, tetere leaf blades 9.8-20.2 × 3.8-7.1 cm, elliptic, thin and rigid, apex acuminate, base obtuse to acute; margin denticulate or undulate ciliolate, glabrous-reticulate or slightly bullate above, with a lax or dense indumentum on veins below composed of appressed squamiform trichomes 0.2-1.2 mm long; venation with 2 pairs of secondary veins arranged laterally to the middle, the inner pair plinerved to 0.9-4.1 $\mathrm{cm}$ above the base, 30-38 tertiary veins, spaced $1.2-3 \mathrm{~mm}$ apart; inflorescences axillary or axillary and terminal, thyrsoid, 4-6.5 cm long, with 20-25 flowers, central axis with 2-3 branching nodes, basal paracladia 2.5-3 cm long, with 1 branch order, twigs with helicoid ends and sessile or subsessile flowers, filiform bracts less than $5 \mathrm{~mm}$ long; flowers not seen; capsule 2.7-3.7 mm long, with 3 locules, pedicels 0.2-0.6 mm long or absent, hypanthium-calyx with a dense indumentum of two trichome types like the branchlets, the shorter $0.3 \mathrm{~mm}$ long and the larger $10.3 \mathrm{~mm}$ long, both appressed subulate-squamiform; seeds numerous, 0.34-0.7 $\mathrm{mm}$ long, cuneiform and with the apical chalazal part short and straight, raphe darker than the testa.

Phenology: all specimens which are in fruit were collected in March and September.

Habitat and distribution: only known from two localities in the Valle del Cauca and Chocó departments in the Pacific plain from sea level to 500 m (Fig. 13).

Conservation status: this species is under-collected and there is insufficient information to provide a definitive conservation assessment. Considering this, I propose a Data Deficient (DD) designation.

Etymology: the epithet refers to the inflorescence position.

Additional specimens examined (paratypes): COLOMBIA. Valle de Cauca, Buenaventura, Bajo Calima, Concesión Pulpapel, bosque pluvial, $100 \mathrm{~m}, 3^{\circ} 56^{\prime} \mathrm{N}, 77^{\circ} 08^{\prime} \mathrm{W}$, 23.VIII.1986, fr., M. Monsalve 1076 (MO). Chocó, Hoya del río San Juan, alrededores de la comunidad indígena Wuananá de Taparalito, 5-10 m, 4²12'N, 77²10'W, 27.III.1979, fr., E. Forero 4257 (COL, MO).

Taxonomic notes: although the type and paratypes of $W$. lateriflora lack flowers, there is certainty about its assignment to the genus Wurdastom due to its acrodromous plinerved leaves, barbellate trichomes, thyrsoid inflorescence, capsular fruit originating from an inferior ovary, and cuneiform seeds. Its lateral inflorescences and appressed subsquamiform trichomes are unique in the ge- 


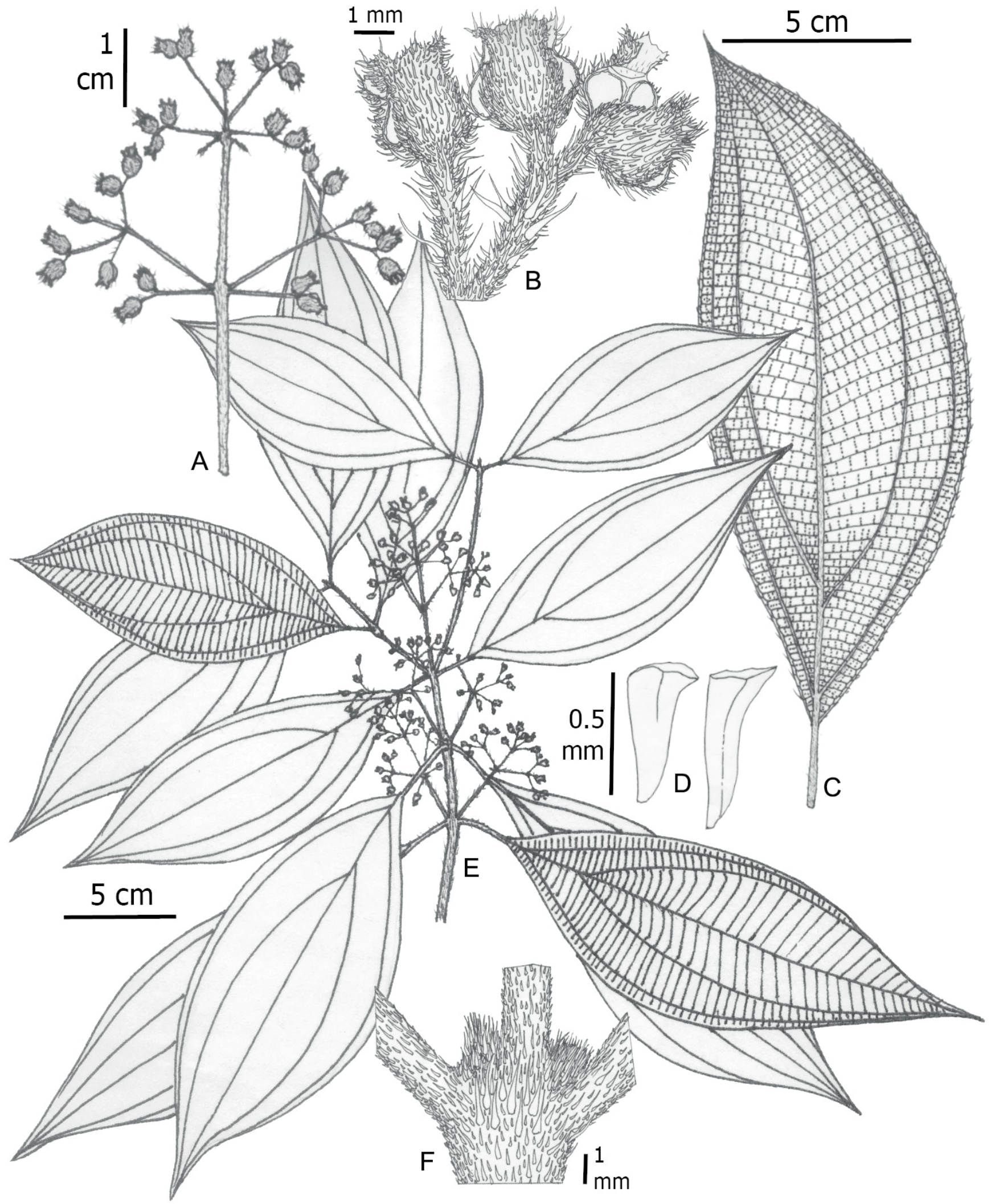

Figure 14: Wurdastom lateriflora Humberto Mend. A. infructescence; B. details of a branch of the infructescence; C. leaf; D. seeds; E. flowering branch; F. node. A-F from Forero 4257 (MO). Line drawing by H. Mendoza-Cifuentes. 
nus. Wurdastom cuatrecasasii is the most similar species to the new taxon, but differs by its terminal pleiothyrsoid inflorescence.

Wurdastom sneidernii (Wurdack) B. Walln., Ann. Naturhist. Mus. Wien 98B(Suppl.): 461. 1996. Figs. 12, 15.

इ Alloneuron sneidernii Wurdack, Phytologia 21(6): 149. 1974. TYPE: COLOMBIA. Cauca, El Tambo, in silva primaeva, La Costa, 1800 m, VII.1936, fl., K. von Sneidern 906 (holotype: $\mathrm{S}$, digital image!).

三 Alloneuron ecuadorense Wurdack, Phytologia 48(3): 246247. 1981. TYPE: ECUADOR. Carchi, Río Blanco drainage above Chical ca $12 \mathrm{~km}$ west of Maldonado, 1300-1500 m, 25.IX.1979, fl., A. Gentry 26552 (holotype: US!; isotype: $\mathrm{MO} !)$

= Wurdastom ecuadorense (Wurdack) B. Walln., Ann. Naturhist. Mus. Wien 98B(Suppl.): 461. 1996. syn. nov.

= Centronia ruizii Lozano-Contreras, Revista Acad. Colomb. Ci. Exact. 23(Suplemento especial): 80-83. 1999. TYPE: COLOMBIA. Cauca, El Tambo, vereda La Romelia, road to Nueva Granada, National Natural Park Munchique, 1950 m, 28.VII.1993, fl., fr., G. Lozano 6713 (holotype: COL!).

Shrubs or trees, 3-7 m, upper internodes subquadrangular; branches, petioles, leaf blades abaxially, inflorescences, hypanthia and calyx densely covered with conic barbellate trichomes, 0.3-2 mm long (type 16); petioles $4-9.5 \mathrm{~cm}$ long, terete, adaxially with trichomes, ca. $1 \mathrm{~mm}$ long; leaf blades $15-33 \times 7.5-19 \mathrm{~cm}$, ovate to oblong ovate, thinly rigid, apex acuminate to caudate, up to $3 \mathrm{~cm}$ long, base obtuse to rounded, margin finely serrulate, bullate-strigose adaxially, enlarged at the bulla-base trichome without enations, 1-2 $\mathrm{mm}$ long (type 15), pubescent below, barbellate conic with enlarged base, trichome 0.1-1.5 $\mathrm{mm}$ long over middle vein (type 15), filament trichomes 0.1-1.5 mm long over $2^{\circ}, 3^{\circ}$ y $4^{\circ}$ veins (type 12); venation with 2-3 pairs of veins arranged laterally to the middle vein, the upper pair plinerved to 0.5-1.5 $\mathrm{cm}$ above de base, 35-50 tertiary veins, separate 3-7 mm; inflorescences terminal, pleiothyrsoid, $11-27 \mathrm{~cm}$ long, central axis with 5-7 branching nodes, peduncle $0.8-3 \mathrm{~cm}$ long, basal paracladia with 2-4 branch orders, flowers sessile or pedicelate; flowers $1.5-1.7 \mathrm{~cm}$ long, (7)8-9(10)-merous, pedicels
1.7-5 mm long; hypanthia at anthesis cupuliform, 4.5-7 mm long, free portion 1.2-2 mm long; externally with a dense indumentum of large conic barbellate trichomes up to $2 \mathrm{~mm}$ long; calyx calyptrate and rupturing into irregular caducous lobes, calyx parts are persistent until fruiting; without dorsal teeth, externally with dense indumentum like the hypanthia; petals 6.5-10 × 4.1-6 mm, wide, ovate to obovate, glabrous, white or pink, apex obtuse to acute, apiculate; filaments 2.5$3.8 \mathrm{~mm}$ long, apical elbow 0.7-1.5 mm long; anthers oblong, 2-4 mm long, with a dorsal oriented pore; ovary (3)4(5)-locular, 1.8-5 mm long, cylindrical to obconic; styles 8-9.2 mm long, straight, glabrous, stigmas punctiform, papillose; capsule globose, 5-8 mm long; seeds L- shaped, with a cordiform appendage, $1.3-1.5 \times 0.05 \mathrm{~mm}$ in the chalazal zone, embryo part 0.3-0.5 × $0.1 \mathrm{~mm}$.

Phenology: collected in flower in January (Alvear et al. 1681), February (Alvear et al. 1772), and July through October, the dry season in the area; collected in fruit in February.

Habitat and distribution: northern Ecuador in the Carchi province and southwest Colombia in the Nariño and Cauca departments on the Pacific slope of the Andes between 1300 and $2500 \mathrm{~m}$ (Fig. 16). In pristine subandean and Andean forests (rainfall >4000 mm/year).

Conservation status: this species has an extent of ocurrence of 1,797,571 $\mathrm{km}^{2}$, and a area of occupancy of less than $16,000 \mathrm{~km}^{2}$. Because of the habitat specificity, the small distribution area and the strong anthropomorphic intervention in the Andean forests of southern Colombia, I recommend a conservation status of Endangered (EN-A2C) for this species.

Additional specimens examined: COLOMBIA. Cauca, Parque Nacional Munchique, Quebrada Curuco, sect. Planchon, 2200 m, 13.X.1984, fl., J. Díaz 8 (FMB). El Tambo, corregimiento Uribe, sector El Palchon, $2347 \mathrm{~m}, 2^{\circ} 41.420^{\prime} \mathrm{N}$, $76^{\circ} 53.503$ 'W, 20.I.2013, fl., M. Alvear et al. 1681 (CAS, COL); El Tambo, vereda La Romelia, La Gallera, 2000 m, 26.VII.1993, fl., C. Barbosa 8719 (COL); El Tambo, Veinte de julio, 2248 m, 13.VIII.2005, fl., S. Camargo 060 (CAUP); El Tambo, Quebrada El Sopladero a La Cabaña, 2100-2500 m, 10.X.1995, fl., N. Ruíz 510 (COL); El Tambo, corredor vial 


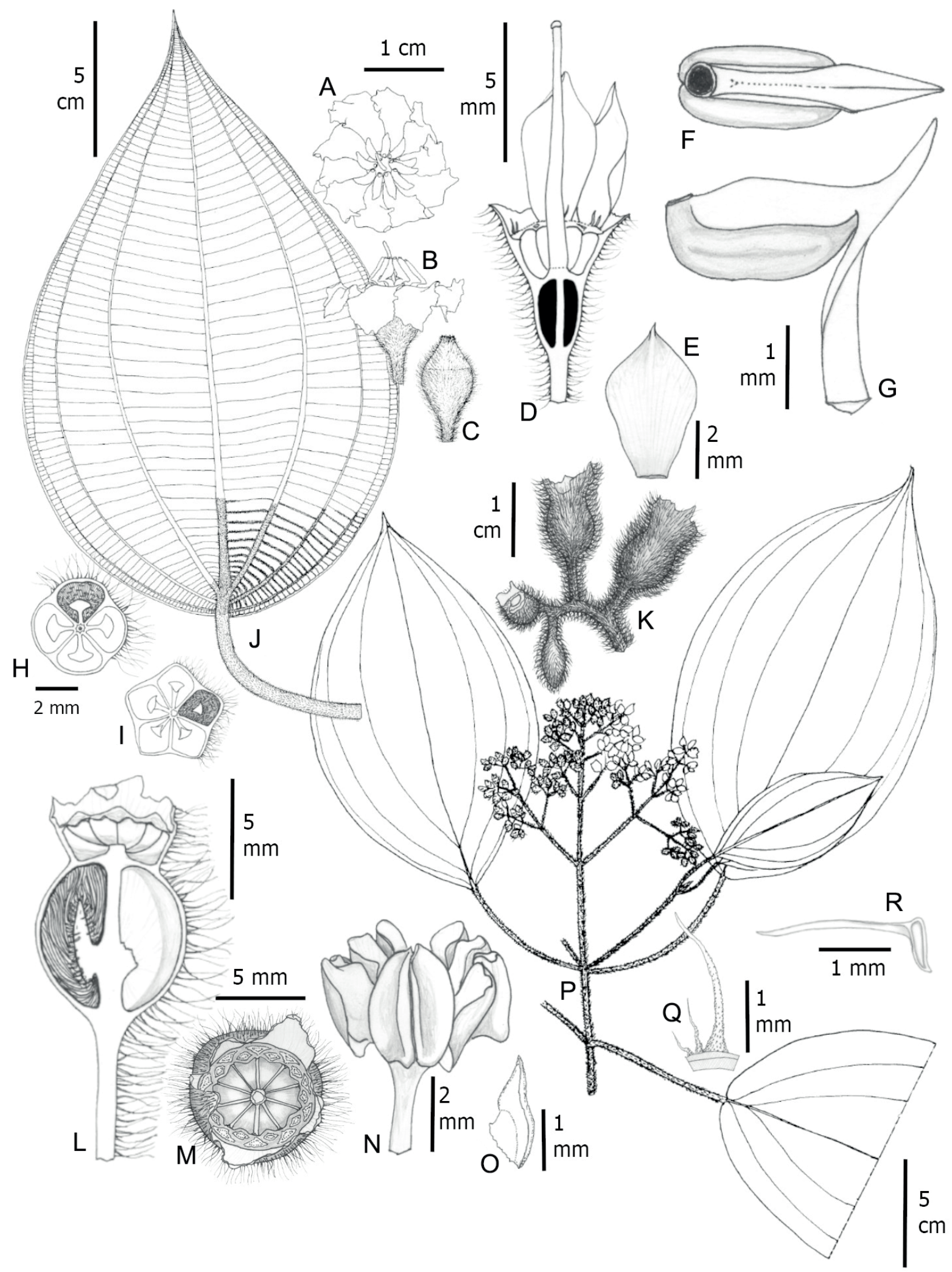

Figure 15: Wurdastom sneidernii (Wurdack) B. Walln. A, B. flower in superior and lateral view; C. floral bud; D. longitudinal section of hypanthium, calyx, ovary and style in lateral view; E. petal; F, G. stamen in dorsal and lateral view; H, I. horizontal section of hypanthium and ovary; J. leaf; K. terminal branch of the infructescence; L. longitudinal section of the fruit before anthesis; $\mathrm{M}$. fruit in superior view; N. old fruit fully open; O. placenta in lateral view; P. flowering (bud) branch; Q. trichome of hypanthium; R. seed. A, B, C, J from Gil 726 (FMB); D, E, F, G, I, R from Ruiz 510 (COL); H, K, L, M, N, O, P, Q from Herrera 9664 (FMB). Line drawing by H. Mendoza-Cifuentes. 

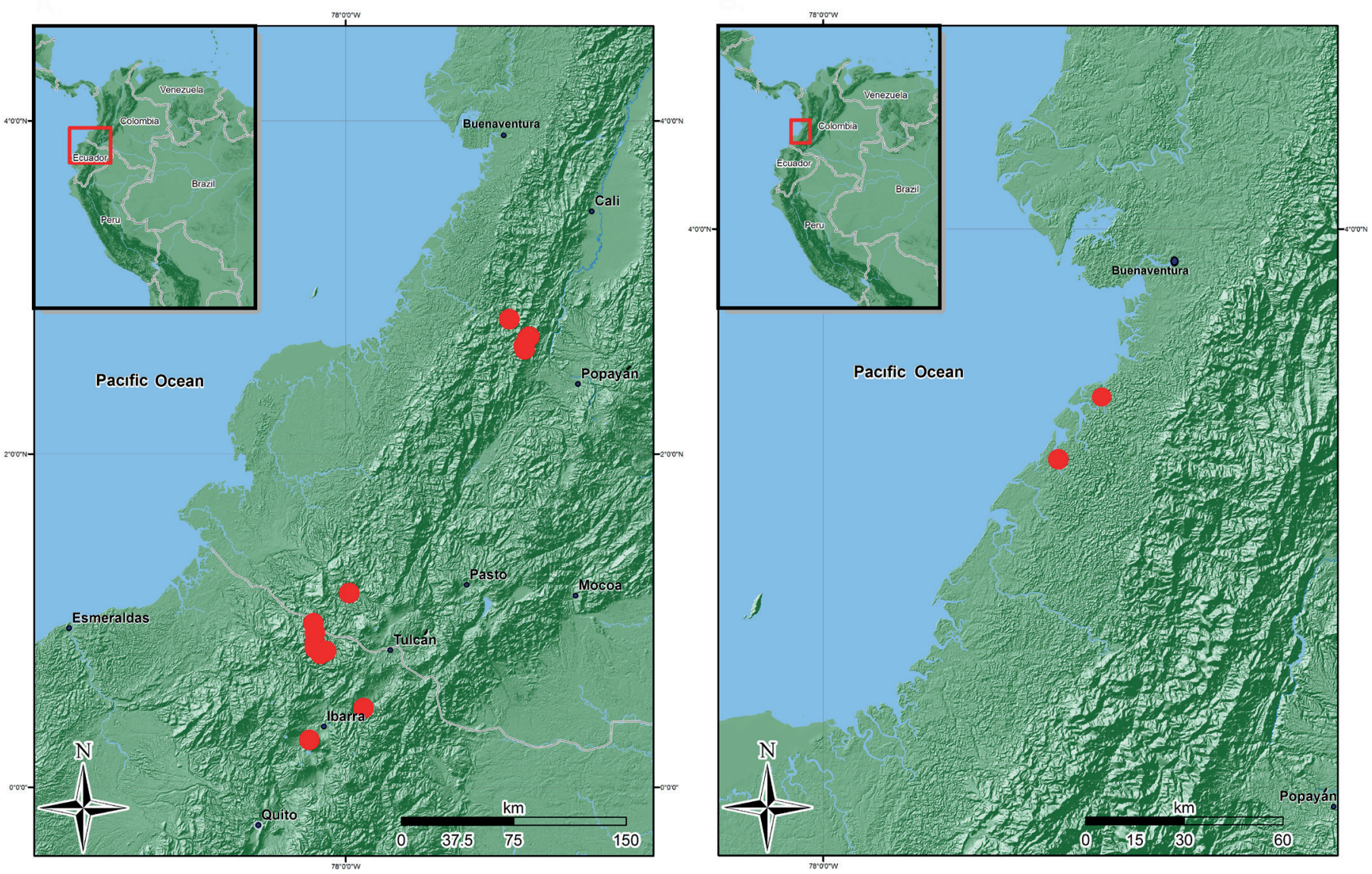

Figure 16: Distribution maps of Wurdastom B. Walln. species. A. Wurdastom sneidernii (Wurdack) B. Walln.; B. W. subglabra (Wurdack) B. Walln.

Veinte de Julio - Las Juntas - Huisito, orillas del río Cocal, 980 m, 14.X.1995, fr., L. Zambrano 455 (PSO). Nariño, Ricaurte, Chucunés, Reserva Natural La Planada, sendero EI Tejón, $1880 \mathrm{~m}, 1^{\circ} 9^{\prime} 25^{\prime \prime} \mathrm{N}, 78^{\circ} 58^{\prime} 42^{\prime \prime} \mathrm{W}, 20.1 .2013$, fl., M. Alvear et al. 1772 (CAS, COL); Reserva Natural Privada La Planada, 1850 m, 13.II.1997, fr., J. Bittner 2753 (FMB); loc. cit., 7.XI.2003, fl., I. Gil 726 (FMB); loc. cit., 5.VI.1997, fr., G. Herrera 9664 (FMB, PSO,); loc. cit., 8.VIII.1995, fl., H. Mendoza 890 (PSO); loc. cit., 5. IX.1999, fr., H. Mendoza 8635 (COL, FMB). ECUADOR. Carchi, Mira, El Carmen, cerro Golondrinas, bosque montano, bosque primario en colinas, 2000-2400 m, 050'N, 78¹1'W, 18.VIII.1994, fl., M. Tirado 1314 (MO, QCNE). Primavera hike about six hours up Río Gualchan drainage to shelter built by Nilo Ortíz at 1950 m, 1930-2200 m, 050'N, 7772'W, 7.VI.1993, fr., J. Bradfor 33 (MO, QCNE). Mira Canton, norte del Carmen, camino a Chical, bosque primario alterado, $2000-2200 \mathrm{~m}, 0^{\circ} 17^{\prime} \mathrm{N}$, 78¹3'W, 10.II.1992, fl., W. Palacios 9721 (MO, QCNE); loc. Cit., fr., W. Palacios 9843 (MO, QCNE). Espejo, Las Juntas - El Corazón, 1500-1600 m, 048'N, 7809'W, 18.VIII.1995, fl., fr., W. Palacios 12414 (MO, QCNE); Cerro Golondrinas, north-facing slope on south side of upper Río Blanco valley, 1750-1800 m, 052'N, 7811'W, 6.II.1993, fr., B. Boyle 1459 (MO, QCNE); Reserva Golondrinas, recorrido de la estación Santa Rosa por el sendero hasta el Cerro Golondrinas, parte baja, $2100 \mathrm{~m}, 0^{\circ} 49^{\prime} \mathrm{N}, 78^{\circ} 07^{\prime} \mathrm{W}, 26.1 .2004$, fr., $H$. Vargas 4506 (MO, QCNE); along new unfinished road from El Chical to El Carmen, departing main El Chical to Peñas Blancas road $0.6 \mathrm{~km}$ W of bridge over Río Chical, just W of El Chical, $1300 \mathrm{~m}, 0^{\circ} 59^{\prime} 01^{\prime \prime N}, 78^{\circ} 11^{\prime} 37^{\prime \prime} \mathrm{W}, 7 . \mathrm{VIII.2004,} \mathrm{fl.,} \mathrm{T.} \mathrm{Croat}$ 93031 (MO, QCNE). 
Taxonomic notes: Centronia ruizii was synonymized by Almeda et al. (2016), but the checklist format did not allow for a discussion explaining the reason for its inclusion in W. seneidernii. Mendoza-Cifuentes and Fernández-Alonso (2011) document that Centronia ruizii has haplostemonous flowers and its characters are not found in the congeneric species, but instead, the great majority match with $W$. sneidernii. The latter authors also note that the types of these two species come from similar elevations and localities that are close to one another in the department of Cauca (Colombia).

Wurdack (981) described Alloneuron ecuadorense ( $=W$. ecuadorense $)$ based on the more dense pubescence on the leaves abaxially on all veins and dorsal stamen spur (elbow) longer than in $W$. sneidernii. Collections of $W$. sneidernii from the department of Cauca show that the pubescence on the abaxial leaf surfaces is also dense on all veins, but that the trichomes are shorter than the type of $W$. ecuadorense. Collections associated with $W$. ecuadorense coming from La Planada (department of Nariño, south of Colombia), have intermediate dimensions in flower size and length of the dorsal stamen spur between the two taxa.

Considering these new synonyms, the set of characters that circumscribe this species are leaves with 2-3 pairs of suprabasal veins arranged laterally to the middle vein, bullate strigose adaxial leaf surfaces, and flowers 7-10-merous. The most similar species is $W$. hexamera. For differences see the discussion of the latter species.

Wurdastom subglabra (Wurdack) B. Walln., Ann. Naturhist. Mus. Wien 98B(Suppl.): 461. 1996. Fig. 17.

झ Alloneuron subglabrum Wurdack, Phytologia 21(6): 364365. 1971. TYPE: COLOMBIA. Valle del Cauca, Costa Pacífica, Río Yurumanguí, veneral forest, 5-50 m, 29.I.944, fl., fr., J. Cuatrecasas 15764 (holotype: US!; isotypes: F!, NY!, VALLE!).

Shrubs or small trees, 1-5 m high, upper internodes terete; glabrous or with lax indumentum on vegetative and floral structures consisting of conic barbellate adpressed trichomes 0.1-1 mm long (type 19); leaves at a node slightly anisophyllous; petioles 2-4 mm long; leaf blades 5.5-15.5 $\times$ 2.5-5.6 cm, ovate, oblong-ovate or elliptic, thinly rigid, apex acuminate, base obtuse to rounded, slightly asymmetric, margin entire to undulate, adaxial and abaxial surfaces glabrous or with scattered squamiform trichomes like points, principal veins in abaxial surface with scattered, appressed conic and slightly roughened trichomes; venation with 2 pairs of veins arranged laterally to the middle veins but only one pair reaching the apex, slightly plinervate $3-14 \mathrm{~mm}$ above the base, 18-26 tertiary veins, separate 3-7 $\mathrm{mm}$; inflorescence terminal, pleiothyrsoid, 2-5.5 cm long, with 10-40 flowers, central axis with 2-6 branching nodes, peduncle lack or to $3 \mathrm{~cm}$ long, basal paracladia 0.7-4 cm long, with 2 branch orders, branchlets apically with agglomerate flowers by reduction of axis, flowers sessile or subsessile; flower 4-5-merous, 1.7-3 mm long, pedicel less than $0.5 \mathrm{~mm}$ long; hypanthium at anthesis cupuliform, 1-1.3 mm long, free portion 0.2-0.4 mm long, externally with lax indumentum of obconic barbellate trichomes; calyx truncate or slightly undulate, thalamus 0.2$0.3 \mathrm{~mm}$ long, external teeth conspicuous, subulate, exceeding the thalamus 0.3-0.4 mm long; petals $1 \times 0.5-0.8 \mathrm{~mm}$, ovate or narrow oblong, externally granulose, apex acute; filaments ca. $1 \mathrm{~mm}$ long, apical elbow $0.3 \mathrm{~mm}$ long; anther obovate, 0.5-0.7 mm long, with a dorsal oriented pore; ovary 3-locular, ca. $0.7 \mathrm{~mm}$ long; style 1-1.3 mm long, straight, glabrous, stigma punctiform; capsule $2 \mathrm{~mm}$ long; seeds abundant, 0.6-0.7 $\mathrm{mm}$ long, pyramidal and with apical chalazal part short and straight.

Common name: the type is referenced by the name "mora".

Phenology: the type with flowers was collected in January, which is the dry season in the region. A second collection in flower and fruits from October.

Habitat and distribution: known only from type locality and a second collection near the mouth of the river Cajambre in pluvial tropical forest. This second collection refers to the habitat Guandal, which is a floodplain forest near the coast dominated by few species of large trees (Fig. 16).

Conservation status: this species is undercollected and there is insufficient information. Considering this, it is cataloged as Data Deficient (DD) designation. 


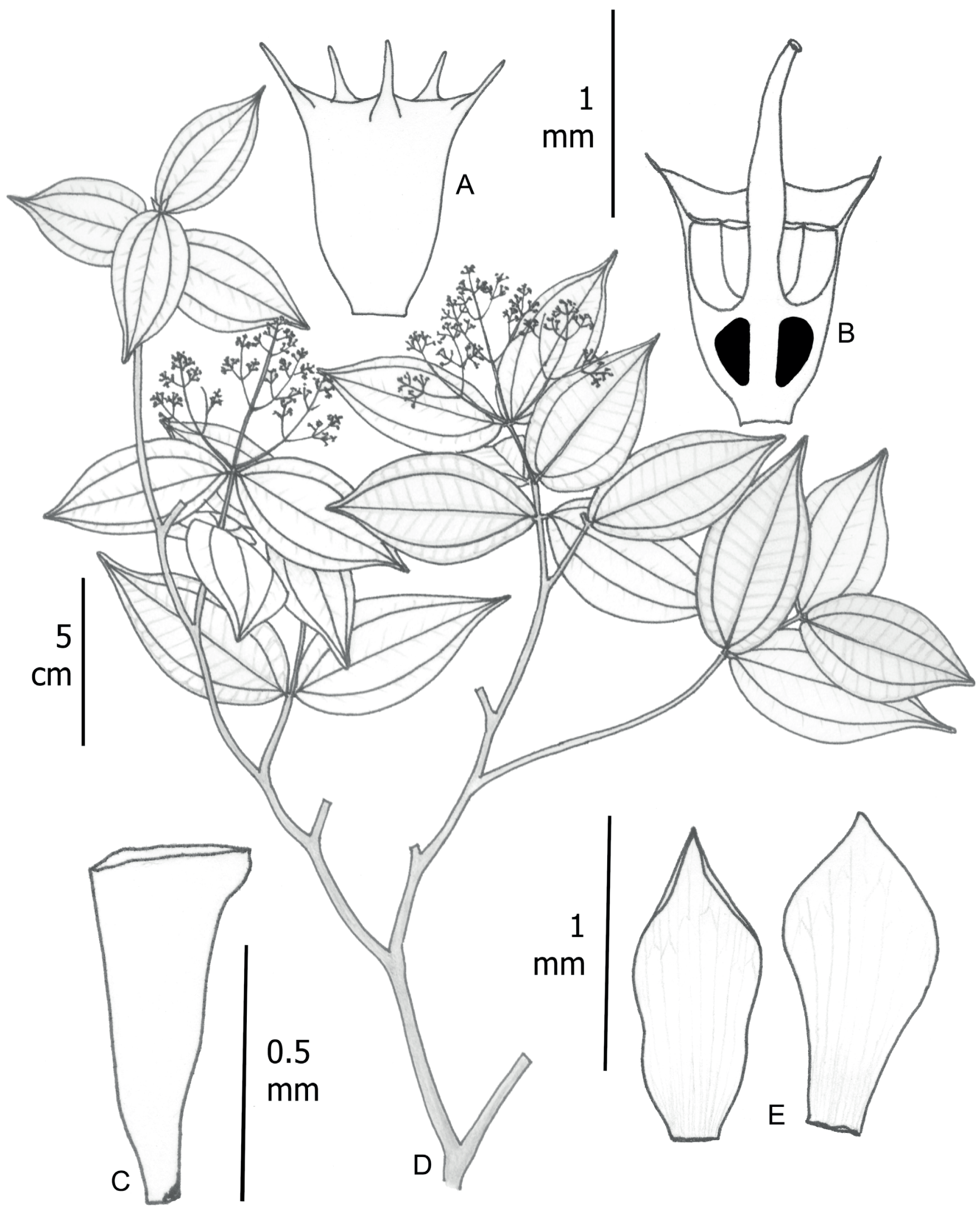

Figure 17: Wurdastom subglabra (Wurdack) B. Walln. A. lateral view of hypanthium and calyx; B. longitudinal section of hypanthium, calyx, ovary and style; C. seed; D. flowering branch; E. petals. A-E from Cuatrecasas 15764 (VALLE). Line drawing by H. Mendoza-Cifuentes. 
Additional specimens examined: COLOMBIA. Valle del Cauca, comunidad de Cajambre, vereda Cuelvadito, alrededor de la parcela permanente instalada por CONIF, $11 \mathrm{~m}, 3^{\circ} 32^{\prime} 53.5^{\prime \prime} \mathrm{N}, 77^{\circ} 15^{\prime} 44.2^{\prime \prime} \mathrm{W}, 24 . X .2014$, fl., fr., $R$. González 3191 (FMB).

Taxonomic notes: the character combination of subsessile leaves and conic barbellate trichomes is not found in other species of Wurdastom or Melastomataceae in its distribution area.

\section{Excluded Collections}

Exsiccates W. Quizhpe 2158, J.E. Madesen 86849 and G. Harling 24065 (QCNE) from Zamora-Chinchipe in Ecuador. These collections are in fruit; I only did a superficial review, and Icould not fully identify them. It is possible it concerns a new species affine to $W$. sneidernii. More collections with flowers are necessary.

\section{Discussion}

Wurdastom is a fairly unknown genus and has never been the subject of a comprehensive study. With this taxonomic review, eight species for the genus restricted to the Neotropics are documented, one of them new for science. Likewise, a unique set of characters is established for its recognition, including growth form (shrub or tree), acrodromous venation, barbellate trichomes, multiflorous thyrsoid or pleiothyrsoid inflorescence, and petals $\leq 1 \mathrm{~cm}$ long.

Most species of Wurdastom have small distribution areas but this is possibly a reflection of the lack of sampling. Of the entire genus, only 57 collections were found in 17 herbaria reviewed, representing an average of six collections for each species. However, two species, $W$. cuatrecasasii and $W$. sneidernii account for $70 \%$ of the collections, while five species, W. bullata, W. dorri, W. dudleyi, $W$. lateriflora, and $W$. subglabra, are known from three or less collections including types. Considering this, five of the treated species are suggested to be categorized as Data Deficient according to IUCN criteria, and only one species is categorized as Threatened ( $W$. sneidernii), and two as Vulnerable (W. cuatrecasasii and W. dudleyi ).

\section{Author contributions}

HMC conceived, acquired the data, reviewed collections, and wrote the document.

\section{Funding}

This study was partially financed with the author's own resources and from the Alexander von Humboldt Institute of Biological Resources Research, Colombia. Likewise, and additionally a scholarship to visit the Califonia Academy of Sciences and review collections from the CAS herbarium.

\section{Acknowledgments}

I would like to thank the Natural Science Institute of the National University of Colombia, the Alexander von Humboldt Institute, and the California Academy of Science. Thanks also to the Herbaria used in this study: CAS, CAUP, COAH, COL, CUVC, F, FMB, HUQ, MO, QCA, QCNE, NY, S. Special thanks to Ricardo Kriebel, Marcela Alvear, Carlos Parra, Fabian Michelangeli, Frank Almeda, Daryn Penneys, Gilberto Ocampo, Roy González and Carlos Ramírez.

\section{Literature cited}

Almeda, F. and O. R. Robinson. 2011. Systematics and phylogeny of Siphanthera (Melastomataceae). Systematic Botany Monographs 93:101.

Almeda, F., H. Mendoza-Cifuentes, D. Penneys, F. A. Michelangeli and M. Alvear. 2016. Melastomataceae. In: Bernal, R., S. R. Gradstein and M. Celis (eds.). Catálogo de Plantas y Líquenes de Colombia. Instituto de Ciencias Naturales, Universidad Nacional de Colombia. Bogotá, Colombia. Pp. 1585-1664. http://catalogoplantasdecolombia.unal.edu. co/es/ (consulted February, 2018).

Bachman, S. and J. Moat. 2012. GeoCAT an open source tool for rapid Red List assessments. http://geocat.kew.org (consulted February 2018).

Gleason, H. A. 1929. Studies on flora of northern South America XII. Bulletin of the Torrey Botanical Club 56(2): 97-112.

Gleason, H. A. 1933. Studies on flora of northern South America - XVIII. Phytologia 1: 25-38. DOI: https://doi.org/10.5962/ bhl.part.18987

IUCN. 2017. Guidelines for using the International Union for Conservation of Nature Red list categories and criteria. Version 
13. Prepared by the Standards and Petitions Subcommittee. http:www.iucnredlist.org/documents/RedListGuidelines. pdf (consulted February, 2018).

Lozano, G. and N. Becerra. 1999. Los géneros Allomaieta y Cyphostyla (Melastomataceae). Revista de la Academia Colombiana de Ciencias 23(86): 5-18.

Mendoza, H. and B. Ramírez. 2006. Guía ilustrada de géneros de Melastomataceae y Memecylaceae de Colombia. Instituto de Investigación de Recursos Biológicos Alexander von Humboldt, Universidad del Cauca. Bogotá, D.C., Colombia. Pp. 1-288.

Mendoza-Cifuentes, H. and J. L. Fernández-Alonso. 2010. Evaluación de caracteres del cáliz y de los estambres en la tribu Merianieae (Melastomataceae) y definición de homologías. Revista de la Academia Colombiana de Ciencias 34(131): 143-172. http://hdl.handle.net/10261/31130 (consulted February, 2018).

Mendoza-Cifuentes, H. and J. L. Fernández-Alonso. 2011. Análisis cladístico de Centronia (Merianieae/Melastomataceae) con base en caracteres morfológicos. Revista de la Academia Colombiana de Ciencias 35(137): 431-450. http://hdl.handle.net/10261/47697f (consulted February, 2018).

Michelangeli., F. A., A. Nicolas, M. E. Morales-P and H. David. 2011. Phylogenetic relationships of Allomaieta, Alloneuron, Cyphostyla, and Wurdastom (Melastomataceae) and the resurrection of the tribe Cyphostyleae. International Journal of Plant Science 172(9): 1165-1178. DOI: https://doi. org/10.1086/662032

Michelangeli, F. A., C. Ulloa-Ulloa and K. Sosa. 2014. Quipuanthus, a new genus of Melastomataceae from the foothills of the Andes in Ecuador and Peru. Systematic Botany 39(2): 533540. DOI: https://doi.org/10.1600/036364414X680924
Renner, S. 1993. Phylogeny and classification of the Melastomataceae and Memecylaceae. Nordic Journal of Botany 13(5): 519-550. DOI: https://doi.org/10.1111/j.1756-1051.1993. tb00096.x

Van der Hammen, T. and J. O. Rangel-Ch. 1997. El estudio de la vegetación en Colombia. In: Rangel, O., P. D. Lowy and M. Aguilar (eds.). Colombia - Diversidad Biótica II - Tipos de vegetación. Instituto de Ciencias Naturales de la Universidad Nacional de Colombia; Instituto de Hidrología, Meteorología y de Estudio Ambientales IDEAM. Bogotá, Colombia. Pp. 17-57.

Wallnöfer, B. 1996. A revision of the genus Alloneuron Pilg. and segregation of Wurdastom gen. $\mathrm{n}$. (Melastomataceae). Annalen des Naturhistorischen Museums in Wien 98B(Suppl.): 447-462.

Wallnöfer, B. 1999. Alloneuron Pilg. (Melatomataceae): some additions. Annalen des Naturhistorischen Museums in Wien 101B: 593-598.

Wurdack, J. J. 1971. Certamen Melastomataceis XVII. Phytologia 21(6): 356-368.

Wurdack, J. J. 1974. Certamen Melastomataceis XXIII. Phytologia 21(6): 135-151.

Wurdack, J. J. 1981. Certamen Melastomataceis XXXII. Phytologia 48(3): 246-247.

Wurdack, J. J. 1986. Atlas of hairs for neotropical Melastomataceae. Smithsonian Contributions to Botany 63: 1-80. DOI: https://doi.org/10.5962/bhl.title.122493

Wurdack, J. J. 1990. Certamen Melastomataceis XXXIX. Phytologia 69(5): 323-324. 